Part of Journal of Research of the National Bureau of Standards, Volume 30, April 1943

\title{
EFFECTS OF ADDED MATERIALS ON SOME PROPERTIES OF HYDRATING PORTLAND CEMENT CLINKERS
}

\author{
By Edwin S. Newman, Raymond L. Blaine, Charles H. Jumper, \\ and George L. Kalousek
}

\begin{abstract}
Studies were made of the effects of added materials on the properties of a group of portland cement clinkers representing standard-portland, moderateheat-of-hydration, high-early-strength, sulfate-resistant, and white cements. The materials used were gypsum, sugar, calcium chloride, TDA (grinding aid), tannic acid, triethanolamine, calcium acetate, and fluosilicic acid. The effects were judged by comparing the results of tests of specimens of clinker pastes containing the materials under investigation with the results of similar tests of the clinker pastes to which nothing had been added.

It was found that although some of the materials caused large changes in the behavior of the clinker pastes during their early history, these eff ects largely disappeared thereafter. Few of the substances had much effect on the results of tests performed at 28 days. No tests were made to evaluate the effect of the added materials after longer periods.
\end{abstract}

\section{CONTENTS}

Page

I. Introduction

II. Materials

1. Clinkers_.

2. Addition agents

III. Procedure

1. Temperature changes of pastes.

2. Condition of the pastes

3. Heats of hydration

4. Strength tests

5. Flows (consistencies)

6. Merriman sugar solubilities.

7. Paul floc tests

IV. Results and discussion

1. Temperature-time curves, condition of the pastes, and flows..-- 286

2. Heats of hydration

3. Strengths

4. Sugar solubility and floc tests

V. Summary

VI. References.... 301

\section{INTRODUCTION}

It is known that many properties of hydrating cements are affected differently by various added materials. That this is also true of commerical portland-cement clinkers ${ }^{1}$ is shown by recent studies [1] ${ }^{2}$ of the aqueous extracts of portland-cement-clinker pastes. The present paper is one of a series dealing with the results of these studies,

1 To avoid confusion, it is to be noted that "clinker" refers to the ground product containing no added substance, whereas "cement" contains gypsum added during grinding.

2 Figures in brackets indicate the literature references at the end of this paper. 


\section{Journal of Research of the National Bureau of Standards}

and is, in part, concerned with the behavior of the pastes from which the filtrates discussed in the preceding paper [1] were removed. The properties investigated were the temperature-time relations and the heats of hydration of the clinker pastes, the strengths of mortar and concrete specimens fabricated from these pastes, the flows of the concretes, the sugar solubilities of the clinkers according to Merriman's procedure [2], and the amounts of floc developed by the clinkers when tested according to Paul's method [3]. The temperature-time curves, the results of the sugar solubility and floc tests, and part of the heats of hydration were determined, using pastes from which no filtrate had been removed.

\section{MATERIALS}

\section{CLINKERS}

To facilitate comparisons, the clinkers are given the same identification numbers in this paper as in preceding publications $[1,8]$. The chemical analyses and computed compound compositions [4] of the 12 clinkers are given in table 1, together with the finenesses as determined by means of the Wagner turbidimeter [5]. Clinkers 1, 2, $3,4,6,7,11$, and 12 were standard, portland-cement clinkers [6]. Clinker 3, although classified as standard-portland, was actually a high-early-strength-cement clinker, probably because of its greater fineness $\left(2,260 \mathrm{~cm}^{2} / \mathrm{g}\right.$, compared to the finenesses of 1,760 to 1,960 $\mathrm{cm}^{2} / \mathrm{g}$ of the other clinkers). Clinkers 5,8 , and 9 were moderateheat-of-hydration clinkers, and clinker 10 was a sulfate-resistant cement clinker.

TABLE 1.-Analyses, calculated compound compositions, and fineness of ground cement clinkers

\begin{tabular}{|c|c|c|c|c|c|c|c|c|c|c|c|c|}
\hline \multirow{2}{*}{\multicolumn{2}{|c|}{ Clinker }} & \multicolumn{10}{|c|}{ Chemical composition } & \multirow{2}{*}{$\begin{array}{l}\text { Loss on } \\
\text { ignition }\end{array}$} \\
\hline & & \multirow[b]{2}{*}{$\begin{array}{l}\mathrm{SiO}_{2} \\
\% \\
23.9 \\
24.9 \\
22.0 \\
22.3 \\
22.8 \\
22.1 \\
21.7 \\
22.4 \\
22.8 \\
26.0 \\
22.4 \\
21.6\end{array}$} & \multirow[b]{2}{*}{$\begin{array}{c}\mathrm{Fe}_{2} \mathrm{O}_{3} \\
\% \\
5.6 \\
0.5 \\
2.5 \\
2.5 \\
4.3 \\
2.5 \\
2.2 \\
4.6 \\
5.3 \\
2.8 \\
2.3 \\
3.9\end{array}$} & \multicolumn{2}{|c|}{$\mathrm{Al}_{2} \mathrm{O}_{3}$} & $\mathrm{CaO}$ & $\mathrm{MgO}$ & \multicolumn{2}{|c|}{$\mathrm{Na}_{2} \mathrm{O}$} & $\mathrm{K}_{2} \mathrm{O}$ & $\mathrm{SO}_{3}$ & \\
\hline $\begin{array}{l}1 \\
2 \\
3 \\
5 \\
6 \\
6\end{array}$ & - & & & & $\begin{array}{l}\% \\
3.4 \\
4.2 \\
5.7 \\
5.8 \\
5.0 \\
5.4 \\
6.8 \\
5.0 \\
4.0 \\
2.6 \\
5.9 \\
6.7\end{array}$ & $\begin{array}{l}\% \\
64.6 \\
64.1 \\
67.6 \\
64.0 \\
62.8 \\
64.7 \\
65.2 \\
64.8 \\
64.7 \\
65.8 \\
64.4 \\
64.7\end{array}$ & $\begin{array}{l}\% \\
0.6 \\
.9 \\
1.1 \\
2.8 \\
2.9 \\
2.6 \\
2.7 \\
2.1 \\
1.4 \\
1.5 \\
3.7 \\
1.3\end{array}$ & & & $\begin{array}{l}\% \\
0.05 \\
.25 \\
.11 \\
1.32 \\
1.05 \\
0.53 \\
.18 \\
.20 \\
.09 \\
.26 \\
.37 \\
.76\end{array}$ & $\begin{array}{l}\% \\
0.09 \\
.00 \\
.01 \\
.51 \\
.37 \\
.18 \\
.32 \\
.30 \\
.35 \\
.12 \\
.12 \\
.28\end{array}$ & $\begin{array}{r}\% \\
1.1 \\
5.3 \\
1.1 \\
0.9 \\
.9 \\
1.3 \\
0.7 \\
.4 \\
.5 \\
.8 \\
.7 \\
.8\end{array}$ \\
\hline \multirow{2}{*}{ Clinker } & \multirow{2}{*}{$\begin{array}{c}\text { Insolu- } \\
\text { ble } \\
\text { residue }\end{array}$} & \multirow{2}{*}{$\begin{array}{l}\text { Free } \\
\text { lime }\end{array}$} & \multirow{2}{*}{\multicolumn{2}{|c|}{$3 \mathrm{CaO} \cdot \mathrm{SiO}_{2}$}} & \multirow{2}{*}{\multicolumn{2}{|c|}{$2 \mathrm{CaO} \cdot \mathrm{SiO}_{2}$}} & \multicolumn{5}{|c|}{ Calculated compound composition } & \multirow{2}{*}{$\begin{array}{l}\text { Fine- } \\
\text { ness }\end{array}$} \\
\hline & & & & & & & \multicolumn{2}{|c|}{$3 \mathrm{CaO} \cdot \mathrm{Al}_{2} \mathrm{O}_{3}$} & \multicolumn{3}{|c|}{$4 \mathrm{CaO} \cdot \mathrm{Al}_{2} \mathrm{O}_{3} \cdot \mathrm{Fe}_{2} \mathrm{O}_{3}$} & \\
\hline $\begin{array}{l}1 \\
2 \\
3 \\
5 \\
6\end{array}$ & $\begin{array}{c}\% \\
0.3 \\
.3 \\
.3 \\
.3 \\
.4 \\
.2 \\
.3 \\
.2 \\
.5 \\
.3 \\
.5 \\
.3\end{array}$ & $\begin{array}{r}\% \\
0.1 \\
5.3 \\
0.7 \\
.4 \\
.2 \\
.9 \\
.8 \\
1.0 \\
0.1 \\
.8 \\
.4 \\
.7\end{array}$ & $\%$ & $\begin{array}{l}50 \\
22 \\
63 \\
47 \\
42 \\
52 \\
50 \\
49 \\
55 \\
45 \\
47 \\
46\end{array}$ & & $\begin{array}{cc}\% & \\
& 31 \\
55 \\
16 \\
29 \\
34 \\
24 \\
25 \\
25 \\
27 \\
24 \\
40 \\
28 \\
27\end{array}$ & $\%$ & $\begin{array}{r}0 \\
10 \\
11 \\
11 \\
6 \\
10 \\
14 \\
6 \\
6 \\
2 \\
2 \\
12 \\
11\end{array}$ & & $\%$ & $\begin{array}{r}17 \\
1 \\
7 \\
8 \\
13 \\
8 \\
7 \\
14 \\
16 \\
9 \\
7 \\
12\end{array}$ & $\begin{array}{c}c m^{2} / g \\
1,760 \\
1,960 \\
2,260 \\
1,850 \\
1,830 \\
1,780 \\
1,840 \\
1,850 \\
1,850 \\
1,820 \\
1,910 \\
1,820\end{array}$ \\
\hline
\end{tabular}


Other characteristics of the clinkers were as follows: Clinker 2 was a white-cement clinker which contained 5.3 percent of free lime and had a loss on ignition of 5.3 percent. Clinkers 4 and 5 were the products of one manufacturer, and clinkers 7 and 8 were the products of another. Each of the remaining clinkers came from a different manufacturer.

Each clinker was ground to the fineness reported in table 1 and stored in an air-tight steel drum.

\section{ADDITION AGENTS}

The materials added were gypsum, calcium chloride, calcium acetate, sugar (sucrose), tannic acid, triethanolamine, TDA (grinding aid), and fluosilicic acid. The gypsum was a commercial mineral product, ground to pass a No. 200 sieve. Analysis showed that it contained 46.7 percent of $\mathrm{SO}_{3}$ and had a loss on ignition of 20.1 percent. The TDA was described by its manufacturers as a mixture of "triethanolamine and highly purified soluble salts of modified lignin sulfonic acids." The remainder of the materials were commercial products of chemically pure quality. The quantities used and the methods of incorporating the added materials are shown in table 2.

TABLE 2.-Addition agents, amounts used, and methods of incorporation

\begin{tabular}{|c|c|c|}
\hline Material & Amount & $\begin{array}{l}\text { Methods } \\
\text { of incor- } \\
\text { poration }\end{array}$ \\
\hline $\begin{array}{l}\text { Gypsum } \\
\text { Calcium chloride } \\
\text { Calcium acetate } \\
\text { Sugar } \\
\text { Tannic acid } \\
\text { Triethanolamine } \\
\text { Fluosilicic acid } \\
\text { TDA }\end{array}$ & $\begin{array}{l}\text { Percent b } \\
3.75 \\
\text { c1.46 } \\
\text { c1. } 15 \\
0.05 \\
.20 \\
.10 \\
\text { c. } 33 \\
.033\end{array}$ & $\begin{array}{l}\text { I } \\
\text { II } \\
\text { II } \\
\text { II } \\
\text { II } \\
\text { II } \\
\text { II } \\
\text { IIA }\end{array}$ \\
\hline
\end{tabular}

a Methods of incorporation: I, The gypsum was mixed with the clinker for $2 \mathrm{hr}$ in a ball mill with a few pebbles; II, these materials were added to the mixing water; and II A, the TDA was added to the mixing water for the determinations of the time-temperature curves, the sugar solubilities, and the amounts of floc. For the remainder of the tests, it was dissolved in 7 times its weight of water, sprinkled on the ground clinker, mixed thoroughly in a ball mill, and the mixture allowed to stand for at least $24 \mathrm{hr}$ before use.

$b$ The gypsum added was 3.75 percent of the mixture, and the other materials were added in the amounts indicated as percentage by weight of the clinker.

- Anhydrous basis.

\section{PROCEDURE}

\section{TEMPERATURE CHANGES OF PASTES}

Determinations of the temperature changes of the pastes were made, using mixtures of $200 \mathrm{~g}$ of clinker and $70 \mathrm{~g}$ of water $(\mathrm{C} / \mathrm{W}$ ratio $=2.86)$. The pastes, contained in small tin cans, were mixed for $1 \mathrm{~min}$ with a high-speed motor-driven stirrer. Copper-constantan thermocouples were inserted in the pastes, and the cans were sealed and placed in stoppered vacuum flasks in a cabinet maintained at $25.0 \pm 0.1^{\circ}$ C. Frequent measurements of the temperature of the pastes were obtained by connecting the thermocouples to a sixpoint recording potentiometer. Details of the test and a description of the apparatus have been published [7,9.] 


\section{CONDITION OF THE PASTES}

Qualitative observations were made of the consistencies of the pastes during mixing and before and after remixing at $2 \mathrm{hr}$.

\section{HEATS OF HYDRATION}

Two procedures were used in determining the heats of hydration. The heat evolved at 12 and $24 \mathrm{hr}$ was estimated from the temperature changes of the pastes as described in the following paragraph. The heats of hydration at 7 and 28 days were determined by the heat-ofsolution method.

The areas under the curves obtained by plotting the temperatures of the pastes against time were measured with a planimeter for the 12- and 24-hr periods. An average value of $0.0675 \mathrm{cal} / \mathrm{hr} \mathrm{deg} \mathrm{g}$ of cement, determined experimentally, was used to calculate the heat lost from the samples of clinker pastes. To the heat thus removed was added the heat stored in the paste by reason of its elevated temperature. The sum of the heat capacities of the cement and water in the paste was used as the heat capacity of the sample. This value, $0.55 \mathrm{cal} / \mathrm{deg} \mathrm{g}$, is somewhat higher than the value $0.41 \mathrm{cal} / \mathrm{deg} \mathrm{g}$ for a well-aged paste obtained by interpolation of the data of Carlson and Forbrich [10]. No account was taken of the heat capacity of the inside of the vacuum flask and the sample container, since nothing was known of the temperature distribution between the thermocouple and the constant-temperature chamber in which the flask was placed. It was estimated that the heat capacity thus neglected was 0.1 to 0.2 $\mathrm{cal} / \mathrm{deg} \mathrm{g}$ of cement.

In determining the heats of hydration by the heat-of-solution method, the procedure described in Federal Specification SS-C-158a was followed with the exception of the method of preparing the paste samples. Large batches of paste $(7,000 \mathrm{~g}$ of clinker plus 2,450 $\mathrm{g}$ of water, $\mathrm{C} / \mathrm{W}=2.86$ ) were prepared for the filtrations $[1,8]$ and samples taken as follows: (1) immediately after mixing, (2) from the same batch after filtration at $7 \mathrm{~min},(3)$ after a paste, the duplicate of that filtered at $7 \mathrm{~min}$, had aged for $1 \mathrm{hr} 55 \mathrm{~min}$ (hereafter designated as 2-hr paste) and had been remixed, (4) after filtration of the $2-h^{\prime}$ paste. The $\mathrm{C} / \mathrm{W}$ ratio of the filtered pastes was restored to 2.86 by the addition of water before the samples were taken. The paste samples were stored in sealed vials at $21^{\circ} \mathrm{C}$ and tested at 7 and 28 days.

In most of the tests the heat of solution of the dry mixture of the clinker and the added material could not be determined directly. Consequently, it was calculated in all tests. The heats of solution and the losses on ignition were determined separately, both for the clinkers and for the materials investigated. Then for each mixture the contribution of each component to the heat of solution and to the residue on ignition was calculated. The ratio of total heat of solution to the total residue was then calculated and taken as the heat of solution of the mixture on an ignited basis. The heat of hydration of the hydrated paste was determined by subtracting its heat of solution from the value thus obtained.

\section{STRENGTH TESTS}

The specimens for the strength tests were fabricated by adding aggregates and water to portions of the filtered paste remaining after 
the heat-of-hydration samples had been taken. No test pieces were made from unfiltered pastes. After fabrication, all specimens were stored at $21^{\circ} \mathrm{C}$ for at least $24 \mathrm{hr}$ in a damp closet having a relative humidity of about 95 percent, and then in water at $21^{\circ} \mathrm{C}$ until tested. The specimens which had no strength at $24 \mathrm{hr}$ were kept in the damp closet for 3 days. The strengths were determined at 1, 3, 7, and 28 days.

The tensile strengths were determined on briquets fabricated from mortar obtained by adding sufficient standard Ottawa sand (20 to $30 \mathrm{mesh}$ ) and water to a portion of the paste to give a 1:3 cementsand mix having a $\mathrm{C} / \mathrm{W}$ ratio of 2.40 .

Compressive strengths were determined on 2-in. cubes made from (a) the same mortar mixture that was used for the briquets and, (b) a concrete mix. The latter was a $1: 3 \frac{1}{2}: 3 \frac{1}{2}$ cement:fine aggregate: coarse aggregate mix with a $\mathrm{C} / \mathrm{W}$ ratio of 1.25 by weight, in which 20 percent of the fine testing sand (Federal Specification SS-C-158a, paragraph F-4m (1)) was replaced by finely ground potter's flint. The coarse aggregate was the portion of Potomac River gravel passing the $3 / 8$-in. sieve and retained on the No. 4 .

The strength specimens were fabricated by a single operator. The concrete specimens were made first, followed in order by the briquets and the mortar cubes. This procedure resulted in the elapse of considerable time between the preparation of the pastes and the fabrication of the briquets and mortar cubes. The pastes were either $1 / 2$ or $2 \frac{1}{2} \mathrm{hr}$ old when received by the operator. Many of the pastes were rather stiff, and the test pieces could not be fabricated properly. For this reason, the most reliable results are those obtained for concretes made of the $1 / 2-\mathrm{hr}$ pastes.

\section{FLOWS (CONSISTENCIES)}

The consistencies of the concrete mixtures were obtained according to the procedure given in Federal Specification SS-C-158a, paragraph $\mathrm{F}-4 \mathrm{~m}(4)$.

\section{MERRIMAN SUGAR SOLUBILITIES}

The sugar solubilities were determined according to Merriman's procedure for cements [2] as follows: Fifteen $\mathrm{g}$ of clinker and $100 \mathrm{ml}$ of a 15-percent sucrose solution were mixed mechanically for $2 \mathrm{hr}$. The mixture was then filtered, and $25 \mathrm{ml}$ of the filtrate was titrated with $0.5 \mathrm{~N} \mathrm{HCl}$. The "end point" was shown by the color change of phenolphthalein, and the "clear point," if the solution was turbid, was obtained by the further addition of acid until turbidity disappeared.

\section{PAUL FLOC TESTS}

The amounts of floc developed were determined according to Paul's procedure [3] as follows: One gram of ground clinker was mixed with $100 \mathrm{ml}$ of distilled water in a Nessler tube, and the tube was stoppered and placed in a horizontal position. The relative amount of flocculent precipitate ("none," "small," etc.) at 7 days was observed and recorded. The precipitate was then filtered off, ignited, and weighed. The amount of floc was reported as a percentage of the total weight of clinker originally taken. 


\section{RESULTS AND DISCUSSION}

\section{TEMPERATURE-TIME CURVES, CONDITION OF THE PASTES, AND FLOWS}

The temperature changes of the pastes, their observed condition during the first $2 \mathrm{hr}$, and the flows of the concretes all help to portray the behavior of the hydrating clinkers during their early history, and are therefore grouped together in the discussion.

Figure 1 presents the temperature changes with time of the pastes, with and without additions, during $24 \mathrm{hr}$ or more after mixing. Figure 2 shows, on an enlarged scale, the temperature changes occurring during the first $3 \mathrm{hr}$. The effects of the various materials are indicated by alteration of the temperatures attained 15 min after mixing the pastes and by changes of the maximum temperatures attained, as well as the times at which they occurred.

In table 3 are listed qualitative observations of the condition of the clinker pastes at various times. The consistency of the concretes, presented as percentage flow in table 4 , may also be taken as indicative of the progress of setting, since the pastes from which the specimens were fabricated were about $1 / 2$ and $2 \frac{1}{2} \mathrm{hr}$ old at the time the measurements were made.

In the following discussion when the statement is made that a substance changed the behavior of a paste, it is to be understood that the change is in comparison with the behavior of the clinker paste alone. No attempt will be made to discuss the behavior of individual clinkers, since detailed information may better be obtained from the tables and curves. There were occasional or even frequent exceptions to the statements made hereafter, but, in general, the effects of the additions were as described in the following paragraphs.

Gypsum reduced the initial temperatures of the pastes as well as the temperatures attained during the first $3 \mathrm{hr}$. The maximum temperatures, however, were increased frequently by rather large amounts, and the times required to reach the maximum temperatures were reduced in many instances. The lower temperatures attained during the first $3 \mathrm{hr}$ were accompanied by increases in the fluidities of many of the pastes. Increased flows were observed for the concretes made from many of the clinkers. Certain of the clinkers exhibited quicksetting, which was eliminated by the addition of gypsum.

Sugar increased the temperatures attained in $15 \mathrm{~min}$ by nearly all the clinkers, but for many of the clinkers also increased the time required to reach the maximum temperatures. The quick-setting which some of the clinkers exhibited was retained, and this was caused in one case when sugar was added. Sugar also increased the flows of the majority of the concretes.

Calcium chloride caused a decrease in the initial temperatures of seven of the clinker pastes and an increase in the initial temperatures of the remainder. Shortly thereafter, however, the temperatures increased rapidly, and at the end of $3 \mathrm{hr}$ the temperatures of the pastes containing calcium chloride were from $5^{\circ}$ to $50^{\circ} \mathrm{C}$ higher than those of the clinker pastes alone. Calcium chloride eliminated the quick-setting exhibited by five of the clinkers. The flows at $1 / 2 \mathrm{hr}$ were increased for nearly all of the clinkers, but at $2 \frac{1}{2} \mathrm{hr}$ the flows were increased for only four of the clinkers and decreased for all but one of the remainder. 


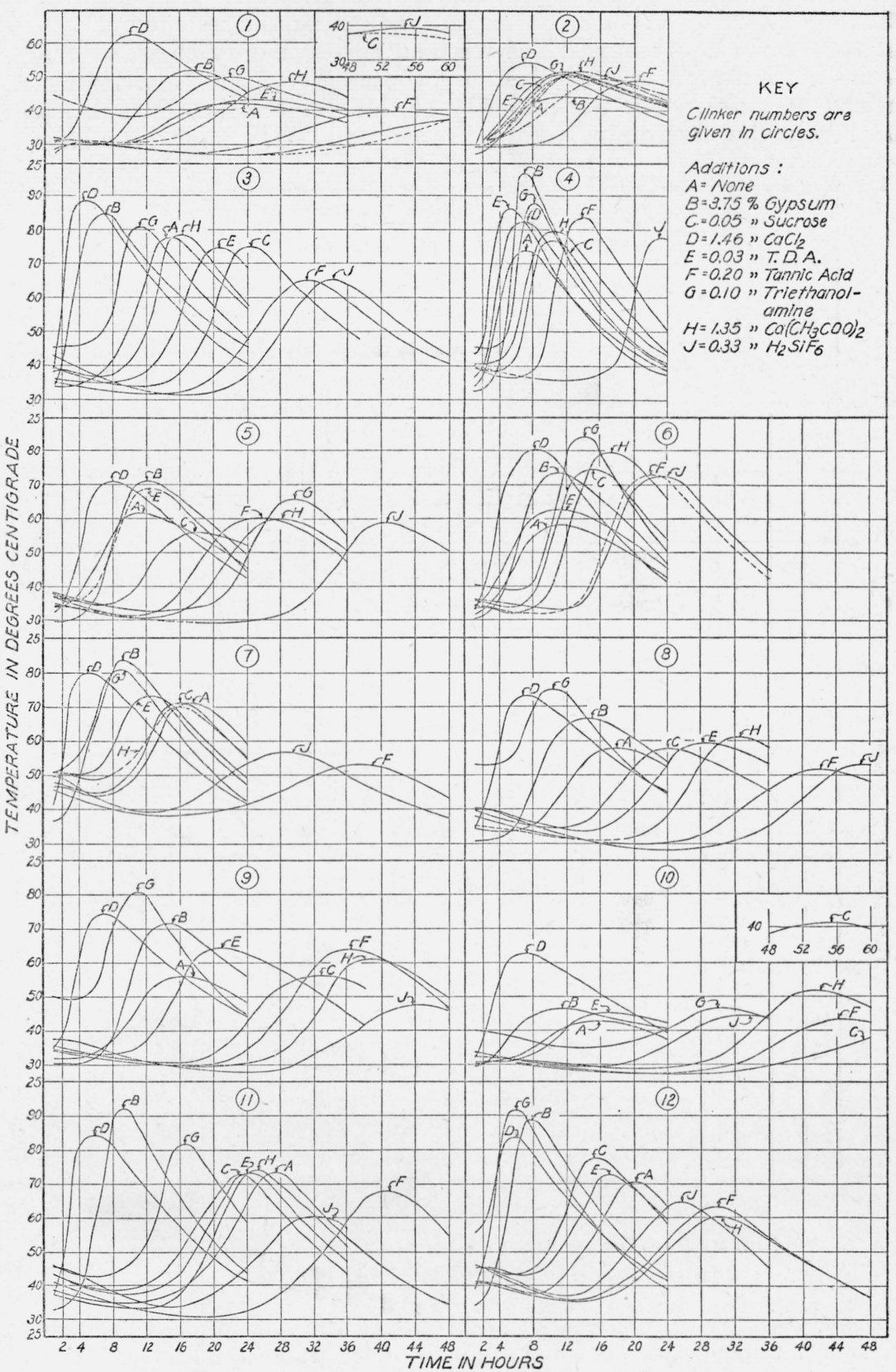

FigURe 1.-Temperatures of hydrating clinker pastes. 


\section{Journal of Research of the National Bureau of Standards}

TDA increased the temperatures attained at $15 \mathrm{~min}$ for nearly all the clinkers. With a few exceptions, the maximum temperatures of the pastes containing TDA were equal to or only slightly greater than the temperatures attained by the clinker pastes containing no added material. For the majority of the clinkers the times required to reach the maximum temperatures were only slightly changed.

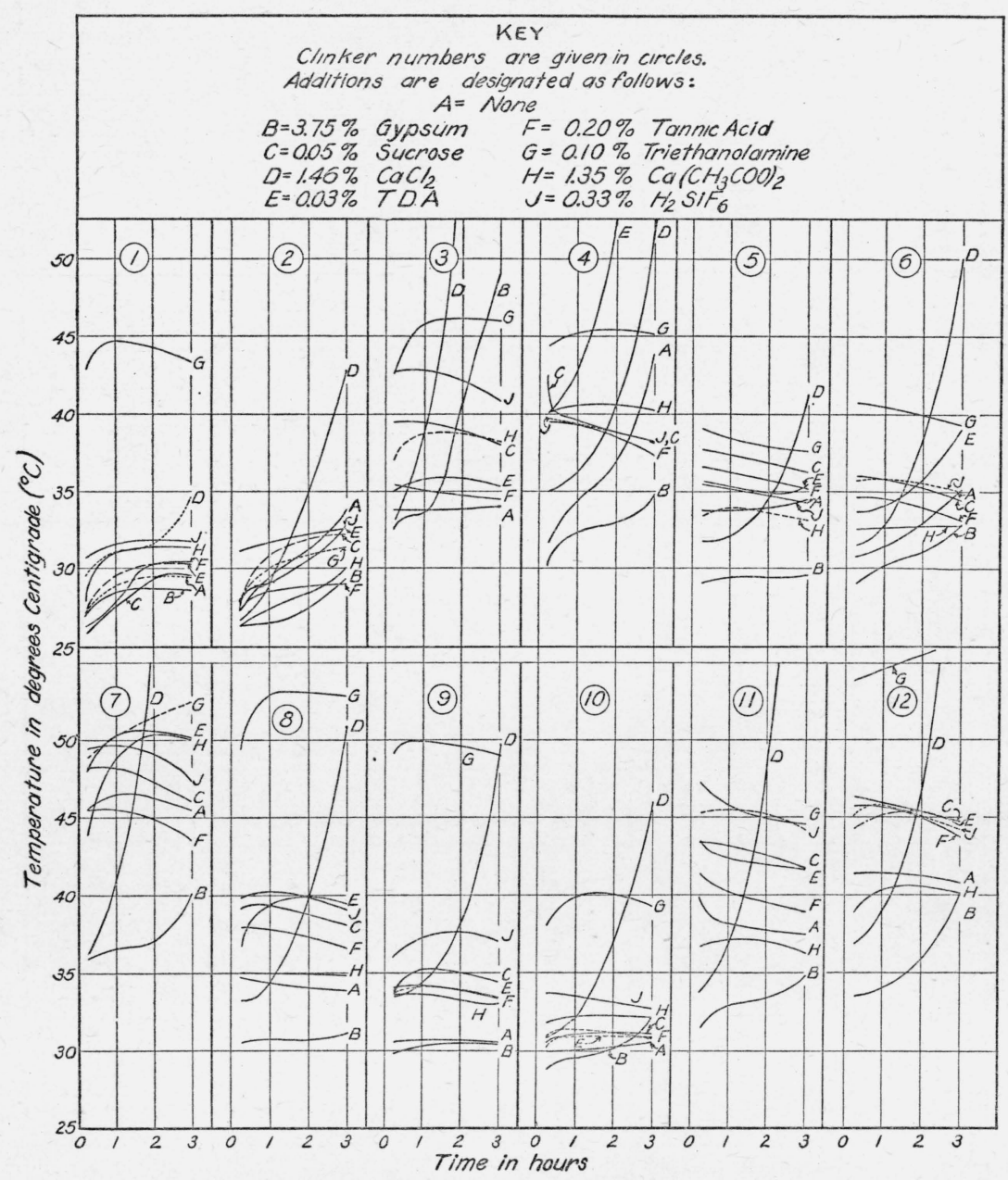

Figure 2.-Temperatures of hydrating clinker pastes during first three hours after mixing.

TDA eliminated quick-setting and reduced the stiffening of the pastes in most instances. This behavior is also indicated in the data of table 4 where the flows of the concretes containing TDA gave the highest averages both at $1 / 2$ and $2 \frac{1}{2} \mathrm{hr}$. With the exception of the effects on the time-temperature curves, many of these changes may have been caused, at least in part, by prehydration, since the TDA was added to the ground clinkers as an aqueous solution $24 \mathrm{hr}$ before the tests were begun. 
TABLE 3.-Condition of cement clinker pastes at various times with and without added materials

\begin{tabular}{|c|c|c|c|c|c|c|c|c|c|c|}
\hline Clinker & Time & No addition & Gypsum & Sugar & $\begin{array}{l}\text { Calcium } \\
\text { chloride }\end{array}$ & TDA & Tannic acid & $\begin{array}{l}\text { Trietha- } \\
\text { nolamine }\end{array}$ & $\begin{array}{l}\text { Calcium } \\
\text { acetate }\end{array}$ & $\begin{array}{l}\text { Fluosilicic } \\
\text { acid }\end{array}$ \\
\hline \multirow{4}{*}{1.} & (During mixing. & Fluid. & Fluid & Fluid. & Fluid & Fluid & Fluid & Fluid & Fluid. & Fluid. \\
\hline & At $2 \mathrm{hr}$ & Soft_. & Soft. & Soft & Stiff.. & Soft & Soft & Hard $a_{-}$ & Sticky & $\begin{array}{l}\text { Fuif. } \\
\text { stiff. }\end{array}$ \\
\hline & After remixing at $2 \mathrm{hr}$ & Fluid. & Plastic & Fluid. & Plastic & Fluid & Fluid & Plastic. & Fluid. & Fluid. \\
\hline & During mixing. & do & Fluid. & .... do & Fluid. & $\ldots . . . \mathrm{d}$ & $\ldots . . . \mathrm{d}$ & Fluid. & & Do. \\
\hline \multirow[t]{2}{*}{2} & At $2 \mathrm{hr}$ & Stiff & Soft & Slightly stiff & Slightly stiff & Soft & Stiff- & Soft & Soft. & Soft. \\
\hline & After remixing at $2 \mathrm{hr}$ & Plastic .. & Fluid - & Sticky ........ & Plastic & Fluid.. & Fluid ... & Fluid ... & Fluid. & Fluid. \\
\hline \multirow{3}{*}{3} & jouring mixing & $\begin{array}{l}\text { Soft_-..... } \\
\text { Stifi }\end{array}$ & Hordo & Fluid & Fluid ... & ...... do & Quickset_. & Quickset & ... do & Do. \\
\hline & $\left\{\begin{array}{l}\text { At } 2 \mathrm{hr} \\
\text { After remixing at } 2 \mathrm{hr}\end{array}\right.$ & Plific... & $\begin{array}{l}\text { Hard } \\
\text { Plastic- }\end{array}$ & $\begin{array}{l}\text { Slightly stiff }-. \\
\text { Fluid }\end{array}$ & $\begin{array}{l}\text { Hard -- } \\
\text { Plastic- }\end{array}$ & Fluid & Soft & Hard...- & Stiff_-- & Stiff. \\
\hline & (During mixing & Fluid... & Fluid... & Quickset...- & Fluid.. & ..... do & Quickset & Quickset & $\begin{array}{l}\text { Stick } \\
\text { Soft }\end{array}$ & Fluid. \\
\hline \multirow[t]{2}{*}{4.} & At $2 \mathrm{hr}$. & Stiff. & Soft & Stiff...... & Stiff. & Soft. & Stiff. & Hard... & Stiff & $\begin{array}{l}\text { Quickset. } \\
\text { Hard. }\end{array}$ \\
\hline & After remixing at $2 \mathrm{hr}$. & Plastic -... & Sticky & Plastic & Plastic - & Fluid & Plastic & Dry & Sticky & \\
\hline \multirow{3}{*}{5} & jDuring mixing & $\begin{array}{l}\text { Quickset b- } \\
\text { Soft }\end{array}$ & $\begin{array}{l}\text { Fluid.... } \\
\text { Soft }\end{array}$ & $\begin{array}{l}\text { Quickset...... } \\
\text { Soft_. }\end{array}$ & $\begin{array}{l}\text { Fluid..- } \\
\text { Soft }\end{array}$ & Soft do & Quickset & Quickset. & Fluid. & Quickset. \\
\hline & $\left\{\begin{array}{l}\text { At } 2 \mathrm{hr} \\
\text { After remixing at } 2 \mathrm{hr}\end{array}\right.$ & $\begin{array}{l}\text { Soft } \\
\text { Sticky. }\end{array}$ & $\begin{array}{l}\text { Soft-.- } \\
\text { Fluid. }\end{array}$ & $\begin{array}{l}\text { Soft } \\
\text { Sticky... }\end{array}$ & Fluid. & $\begin{array}{l}\text { Sooft } \\
\text { Fluid.- }\end{array}$ & $\begin{array}{l}\text { Hard } \\
\text { Plastic.-- }\end{array}$ & Ḧard & $\begin{array}{l}\text { Soft } \\
\text { Fluid }\end{array}$ & Hard. \\
\hline & (During mixing & Fluid. & & Quickset & .... do & & Quickse & Quickse & Flu1 & $\begin{array}{l}\text { Plastic. } \\
\text { Quickset. }\end{array}$ \\
\hline \multirow[t]{3}{*}{6 . } & At $2 \mathrm{hr}$ & Slightly stiff & Soft.- & Slightly stiff & Slightly stiff. & Soft. & Stiff. & Hard. & Soft. & $\begin{array}{l}\text { Quickset. } \\
\text { Hard. }\end{array}$ \\
\hline & After remixing at $2 \mathrm{hr}$ & Plastic _. & Fluid. & Soft & Fluid . & Fluid. & Sticky. & Plastic . & Fluid. & Plastic. \\
\hline & During mixing .............. & Quickset. & do & Quickset & ..... do & ..... do & Quickset & Quickset & do do & Quickset. \\
\hline \multirow[t]{3}{*}{7} & At $2 \mathrm{hr}$ & Hard & Slightly stiff & Hard... & Hard... & Hard.. & Hard. & Ḧard..... & Hard. & Hard. \\
\hline & After remixing at $2 \mathrm{hr}$. & Plastic_. & Soft & Plastic. & Plastic & Soft.-. & Plastic. & Dry. & Sticky & Plastic. \\
\hline & During mixin & Quickset. & Fluid_ & Quickset & Fluid. & Fluid. & Quickset & Quickset & Fluid & Quickset \\
\hline \multirow[t]{2}{*}{8} & At $2 \mathrm{hr}$ & Slightly stiff- & Soft. & Slightly stiff. & Hard & Slightly stiff & Stiff.. & Hard. & Soft & Stifi. \\
\hline & After remixing at $2 \mathrm{hr}$ & Plastic ...... & Fluid. & Fluid.. & Fluid & Fluid & Plastic & Dry & Plastic & Plastic. \\
\hline \multirow[t]{3}{*}{9.} & $\left\{\begin{array}{l}\text { During mixing } \\
\text { At } 2 \mathrm{hr}\end{array}\right.$ & $\begin{array}{l}\text { Fluid } \\
\text { Slightly stiff }\end{array}$ & Soft do & Soft do & Stiff do & Soft & $\begin{array}{l}\text { Fluid } \\
\text { Soft }\end{array}$ & $\begin{array}{l}\text { Quickset } \\
\text { Hard }\end{array}$ & $\begin{array}{l}\text { Fluid } \\
\text { Soft }\end{array}$ & Fluid. \\
\hline & After remixing at $2 \mathrm{hr}$ & $\begin{array}{l}\text { Slignty stiII } \\
\text { Fluid....... }\end{array}$ & Fluid. & Fluid & Fluid. & Fluid & Fluid & $\begin{array}{l}\text { Hard } \\
\text { Plastic. }\end{array}$ & $\begin{array}{l}\text { Soft } \\
\text { Sticky }\end{array}$ & $\begin{array}{l}\text { Stiff. } \\
\text { Fluid. }\end{array}$ \\
\hline & $\left\{\begin{array}{l}\text { During mixing } \\
\text { At } 2 \mathrm{hr}\end{array}\right.$ & Slightly stiff & Soft & Stiff & Stiffo & Soft & Slightly stiff & Quick & & Do. \\
\hline \multirow{2}{*}{1} & $\left\{\begin{array}{l}\text { At } 2 \mathrm{hr} \\
\text { After remixing at } 2 \mathrm{hr}\end{array}\right.$ & $\begin{array}{l}\text { Slightly stiff } \\
\text { Fluid. }\end{array}$ & $\begin{array}{l}\text { Soft } \\
\text { Fluid }\end{array}$ & Stiff & $\begin{array}{l}\text { Stiff -- } \\
\text { Fluid. }\end{array}$ & $\begin{array}{l}\text { Soft-- } \\
\text { Fluid }\end{array}$ & $\begin{array}{l}\text { Slightly sti } \\
\text { Fluid }\end{array}$ & $\begin{array}{l}\text { Stiff - } \\
\text { Plastic }\end{array}$ & $\begin{array}{l}\text { Soft } \\
\text { Fluid }\end{array}$ & $\begin{array}{l}\text { Soft. } \\
\text { Fluid. }\end{array}$ \\
\hline & (During mixing & Quickset. & & Quickset & & & Quickset & Quickse & Soft. & Quickset. \\
\hline \multirow[t]{2}{*}{11} & At $2 \mathrm{hr}$ & Stiff --. & Soft & Stiff & Hard & Stiff & & Hard.- & $\ldots . . .-d$ & $\begin{array}{l}\text { Stiff. } \\
\text { Stit. }\end{array}$ \\
\hline & After remixing at $2 \mathrm{hr}$... & Plastic & Plastic .- & Plastic & Plastic_. & Fluid. & Plastic - & Plastic - & Sticky & Plastic. \\
\hline & $\left\{\begin{array}{l}\text { During mixing } \\
\text { At } 2 \mathrm{hr}\end{array}\right.$ & $\begin{array}{l}\text { Quickset_.... } \\
\text { Hard....... }\end{array}$ & $\begin{array}{l}\text { Fluid } \\
\text { Slightly stiff }\end{array}$ & $\begin{array}{l}\text { Quickset. } \\
\text { Hard.... }\end{array}$ & $\begin{array}{l}\text { Fluid } \ldots . . . \\
\text { Hard.... }\end{array}$ & Slightly stiff. & $\begin{array}{l}\text { Quickset.... } \\
\text { Hard }\end{array}$ & Quickset & $\begin{array}{l}\text { Fluid ... } \\
\text { Stiff.... }\end{array}$ & $\begin{array}{l}\text { Quickset. } \\
\text { Hard. }\end{array}$ \\
\hline & After remixing at $2 \mathrm{hr}$. & Plastic.... & Plastic.. & Plastic.. & Plastic.. & Plastic .... & Plastic. & & Sticky & Plastic. \\
\hline
\end{tabular}

" "Hard" in each case indicates that the material could be reworked only by vigorous hammering with a heavy steel tamper.

The condition of the paste designated as "quickset" indicates that vigorous mixing

a marked decrease in workability. There were different degrees of quick setting. The pastes showing quickset that could be eliminated by mixing without apparent decrease mixing of these pastentiled by italic type, no appreciable heat was evolved during the 
TABLE 4.-Flows of concrete mixes with and without added materials at $1 / 2$ and $21 / 2 \mathrm{hr}$ after initial mixing of cement clinker pastes

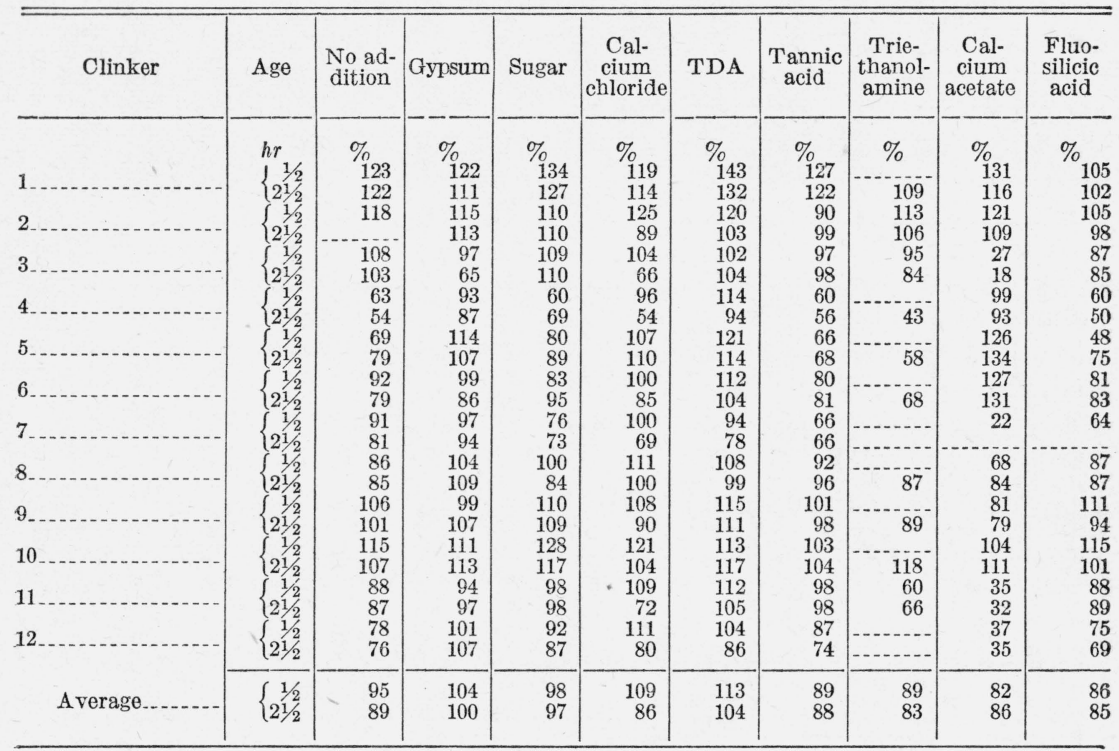

Tannic acid increased the temperatures attained in $15 \mathrm{~min}$ by all but four of the clinker pastes. The maximum temperatures were increased for only three of the clinkers and were decreased or unchanged for the remainder. The times required to reach the maximum temperatures were increased. All but three of the clinker pastes stiffened more rapidly when tannic acid was used. The majority of the flows were affected only slightly or not at all.

Triethanolamine increased markedly the temperatures reached in $15 \mathrm{~min}$ and also increased the maximum temperatures attained. The times required to reach the maximum temperatures were decreased for six of the clinkers and changed only slightly or increased for the remainder. Ten of the clinkers showed quick-setting. The flows of nearly all the concretes were decreased. Two of the clinkers showed little change in the stiffness of the pastes and in the flows of the concretes. In some instances, the flows could not be determined when triethanolamine was added.

Calcium acetate either increased or decreased by a small amount the temperatures attained by the pastes at $15 \mathrm{~min}$. The times required to reach the maximum temperatures were increased. Calcium acetate eliminated the quick-setting exhibited by five of the clinker pastes. In many cases the pastes became very sticky. The flows of the concretes made from six of the clinkers were decreased, whereas the remainder were either increased or not greatly affected.

Fluosilicic acid increased the temperatures attained at $15 \mathrm{~min}$ for nearly all the clinkers. The maximum temperatures were decreased for a majority of the clinker pastes, and the times required to reach the maximum temperatures were increased. Quick-setting was retained and, in two instances, was caused by fluosilicic acid. The flows of the concretes made from five of the clinkers were decreased, whereas the remainder were affected only slightly or not at all. 


\section{HEATS OF HYDRATION}

The heats of hydration determined by the heat-of-solution method are given in table 5. Those determined from the time-temperature curves are included in table 6 . The treatment of the pastes filtered at 7 min most nearly approximates that of the pastes for which the time-temperature curves were obtained. Accordingly, the heats of hydration at 7 and 28 days of the 7 -min pastes sampled before filtration, were made a part of table 6 .

It will be noted in table 6 that in 9 out of 108 cases the 1-day heat of hydration equals or exceeds the heat of hydration at 7 days. Each determination is subject to error, and the net effect of individual errors in the two determinations may occasionally cause the 1-day heat of hydration to appear to exceed that at 7 days when this does not actually happen. However, it may well be that the paste at an elevated temperature in the vacuum flask hydrates to a greater extent in 1 day than the corresponding paste, stored at $21^{\circ} \mathrm{C}$, hydrates in 7 days. $^{3}$ In spite of differences between the two methods, it was felt that the approximate heats of hydration at $1 / 2$ and 1 day were of sufficient interest to be included in the paper. The heats of hydration at $1 / 2,1,7$, and 28 days have been calculated as percentages of the heat of hydration of the clinker without addition and are presented in table 7 and figure 3. In this manner the direct comparison of heats of hydration measured by different methods is avoided.

For convenience, the level of significance of differences in percentages taken from table 7 was arbitrarily set at 10 percent for the $1 / 2$ and 1-day and at 5 percent for the 7- and 28-day heats of hydration, respectively. That is, if a material caused a change in the heat of hydration of less than \pm 10 percent at $1 / 2$ and 1 day and \pm 5 percent at 7 and 28 days, it is stated in the discussion that no change occurred. Statistical investigation of the heats of hydration shown in table 5 and of other similar data obtained in this laboratory indicates that in these measurements differences of less than $4 \mathrm{cal} / \mathrm{g}$ are probably not significant. The reader should bear this in mind in studying table 5 for detailed information on the effects of various additions and the influence of filtration of the pastes at the two ages.

The behavior of the individual cements may be followed in the tables or traced in figure 3 . There were occasional exceptions but, in general, the effects of the additions were as described hereafter.

Gypsum increased the heats of hydration at $1 / 2$ day, sometimes by several hundred percent. At 1 day, two-thirds of the heats of hydration were increased by an average of 30 percent. The changes at 7 days were small, whereas at 28 days most of the heats of hydration were unchanged.

Sugar reduced the heats of hydration of half of the clinkers at $1 / 2$ day by an average of 48 percent. On the other hand, three heats of hydration were increased by nearly the same amount. At 1 day, one-third of the heats of hydration were decreased by an average of 47 percent, and one-third were increased by about half as much. At 7 and 28 days a few more increases than decreases in the heats of hydration occurred, but the changes were small.

3 The differences between the 1-and 7-day heats' of hydration for the 9 cases were small except when TDA was used. In these two cases the differences may have been caused by the different methods of incorporating the TDA. 
TABLE 5.-Heats of hydration of cement clinker pastes with and without added materials

\begin{tabular}{|c|c|c|c|c|c|c|c|c|c|c|c|c|c|c|c|c|c|c|c|c|}
\hline \multirow{2}{*}{ Clinker } & \multirow{2}{*}{$\begin{array}{c}\text { Age of } \\
\text { hydrat- } \\
\text { ing } \\
\text { paste }\end{array}$} & \multirow{2}{*}{$\begin{array}{l}\text { Sam- } \\
\text { pled a }\end{array}$} & \multicolumn{2}{|c|}{$\begin{array}{l}\text { No addition } \\
\text { Filtered at - }\end{array}$} & \multicolumn{2}{|c|}{$\begin{array}{l}\text { Gypsum } \\
\text { Filtered at - }\end{array}$} & \multicolumn{2}{|c|}{$\underset{\text { Filtered at }-}{\text { Sugar }}$} & \multicolumn{2}{|c|}{$\begin{array}{c}\text { Calcium } \\
\text { chloride } \\
\text { Filtered at - }\end{array}$} & \multicolumn{2}{|c|}{$\underset{\text { Filtered at - }}{\mathrm{TDA}}$} & \multicolumn{2}{|c|}{$\begin{array}{c}\text { Tannic acid } \\
\text { Filtered at - }\end{array}$} & \multicolumn{2}{|c|}{$\begin{array}{l}\text { Triethanolamine } \\
\text { Filtered at - }\end{array}$} & \multicolumn{2}{|c|}{$\begin{array}{c}\text { Calcium } \\
\text { acetate } \\
\text { Filtered at - }\end{array}$} & \multicolumn{2}{|c|}{$\begin{array}{c}\text { Fluosilicic } \\
\text { acid } \\
\text { Filtered at - }\end{array}$} \\
\hline & & & $7 \mathrm{~min}$ & $2 \mathrm{hr}$ & $7 \mathrm{~min}$ & $2 \mathrm{hr}$ & $7 \mathrm{~min}$ & $2 \mathrm{hr}$ & $7 \mathrm{~min}$ & $2 \mathrm{hr}$ & $7 \min$ & $2 \mathrm{hr}$ & $7 \mathrm{~min}$ & $2 \mathrm{hr}$ & $7 \mathrm{~min}$ & $2 \mathrm{hr}$ & $7 \mathrm{~min}$ & $2 \mathrm{hr}$ & $7 \mathrm{~min}$ & $2 \mathrm{hr}$ \\
\hline & Days & & $\mathrm{cal} / \mathrm{g}$ & $\mathrm{cal} / \mathrm{g}$ & $\mathrm{cal} / \mathrm{g}$ & cal /g & $\mathrm{cal} / \mathrm{g}$ & $\mathrm{cal} / \mathrm{g}$ & $\mathrm{call}_{67}$ & $\mathrm{cal} / \mathrm{g}_{59}$ & $\mathrm{cal} / \mathrm{g}$ & $\mathrm{cal} / \mathrm{g}$ & $\mathrm{cal} / \mathrm{g}$ & $\mathrm{call} / \mathrm{g}$ & $\mathrm{cal} / \mathrm{g}$ & $\mathrm{cal} / \mathrm{g}$ & $\mathrm{cal} / \mathrm{g}$ & callg & $\mathrm{cal} / \mathrm{g}$ & $\mathrm{cal} / \mathrm{g}$ \\
\hline & $\begin{array}{l}7 \\
7\end{array}$ & $\begin{array}{l}\mathrm{Bf} \\
\mathrm{Af}\end{array}$ & $\begin{array}{l}49 \\
49\end{array}$ & $\begin{array}{l}49 \\
50\end{array}$ & $\begin{array}{l}49 \\
50\end{array}$ & $\begin{array}{l}55 \\
59\end{array}$ & $\begin{array}{l}49 \\
50\end{array}$ & $\begin{array}{l}52 \\
51\end{array}$ & $\begin{array}{l}67 \\
66\end{array}$ & $\begin{array}{l}59 \\
59\end{array}$ & $\begin{array}{l}48 \\
52\end{array}$ & $\begin{array}{l}50 \\
50\end{array}$ & $\begin{array}{l}47 \\
50\end{array}$ & $\begin{array}{l}57 \\
54\end{array}$ & $\begin{array}{l}70 \\
74\end{array}$ & & $\begin{array}{l}59 \\
62\end{array}$ & $\begin{array}{l}64 \\
63\end{array}$ & & \\
\hline $1 .-$ & 28 & $\mathrm{Bf}$ & 72 & 75 & 73 & 67 & 74 & 74 & 76 & 68 & 73 & 78 & 67 & 75 & 81 & 78 & $\begin{array}{l}02 \\
87\end{array}$ & $\begin{array}{l}03 \\
85\end{array}$ & $\begin{array}{l}58 \\
74\end{array}$ & $\begin{array}{l}04 \\
72 \\
72\end{array}$ \\
\hline & 28 & Af & 72 & 76 & 69 & 65 & 72 & 74 & 72 & 68 & 68 & 71 & 67 & 75 & 77 & 78 & 85 & 84 & 75 & 72 \\
\hline \multirow{4}{*}{2} & 7 & Bf & $\begin{array}{l}45 \\
42\end{array}$ & 47 & 42 & 49 & 48 & 50 & 41 & 43 & 46 & 49 & 41 & 50 & 52 & 56 & 50 & 62 & 60 & 57 \\
\hline & $\begin{array}{r}7 \\
28\end{array}$ & $\begin{array}{l}\mathrm{Af} \\
\mathrm{Bf}\end{array}$ & $\begin{array}{l}42 \\
56\end{array}$ & $\begin{array}{l}43 \\
51\end{array}$ & $\begin{array}{l}39 \\
58\end{array}$ & $\begin{array}{l}48 \\
59\end{array}$ & 43 & $\begin{array}{l}46 \\
69\end{array}$ & $\begin{array}{l}39 \\
55\end{array}$ & 39 & 43 & 48 & 41 & 45 & 53 & 53 & 55 & 55 & 57 & 54 \\
\hline & 28 & Af & 52 & $\begin{array}{l}51 \\
51\end{array}$ & $\begin{array}{l}58 \\
59\end{array}$ & $\begin{array}{l}59 \\
57\end{array}$ & $\begin{array}{l}65 \\
65\end{array}$ & $\begin{array}{l}69 \\
69\end{array}$ & $\begin{array}{l}50 \\
56\end{array}$ & $\begin{array}{l}57 \\
55\end{array}$ & $\begin{array}{l}66 \\
61\end{array}$ & $\begin{array}{l}63 \\
64\end{array}$ & $\begin{array}{l}68 \\
65\end{array}$ & $\begin{array}{l}65 \\
64\end{array}$ & $\begin{array}{l}72 \\
68\end{array}$ & $\begin{array}{l}73 \\
65\end{array}$ & 69 & 77 & 64 & 64 \\
\hline & 7 & $\mathrm{Bf}$ & 82 & 81 & 82 & 83 & 84 & 84 & 80 & 77 & 76 & $\begin{array}{l}79 \\
79\end{array}$ & 78 & 76 & $\begin{array}{l}08 \\
93\end{array}$ & $\begin{array}{l}03 \\
96\end{array}$ & $\begin{array}{l}09 \\
92\end{array}$ & 87 & $\begin{array}{l}64 \\
84\end{array}$ & $\begin{array}{l}\text { D3 } \\
87\end{array}$ \\
\hline \multirow[t]{3}{*}{3.} & 7 & Af & 79 & 79 & 77 & $\begin{array}{r}80 \\
\end{array}$ & 82 & $\begin{array}{r}79 \\
100\end{array}$ & 78 & 80 & 75 & 77 & 77 & 76 & 88 & 89 & 88 & 87 & 86 & 89 \\
\hline & $\begin{array}{l}28 \\
28\end{array}$ & $\mathrm{Bf}$ & 105 & 98 & 107 & 102 & 92 & 100 & 91 & 95 & 99 & 93 & 97 & 100 & 103 & 102 & 105 & 99 & 102 & 101 \\
\hline & $\begin{array}{r}28 \\
7\end{array}$ & Af & $\begin{array}{r}101 \\
70\end{array}$ & 96 & 96 & $\begin{array}{l}96 \\
68\end{array}$ & $\begin{array}{l}95 \\
79\end{array}$ & 99 & 88 & 92 & 96 & 96 & 94 & 94 & 101 & 9 & 102 & 98 & 100 & 100 \\
\hline \multirow{4}{*}{4} & 7 & Af & 67 & 67 & 67 & 70 & 77 & 72 & 64 & $\begin{array}{l}63 \\
64\end{array}$ & $\begin{array}{l}71 \\
69\end{array}$ & $\begin{array}{l}69 \\
63\end{array}$ & $\begin{array}{l}75 \\
76\end{array}$ & $\begin{array}{l}72 \\
73\end{array}$ & & $\begin{array}{l}68 \\
70\end{array}$ & $\begin{array}{l}83 \\
83\end{array}$ & $\begin{array}{l}87 \\
82\end{array}$ & $\begin{array}{l}78 \\
81\end{array}$ & $\begin{array}{l}77 \\
79\end{array}$ \\
\hline & 28 & $\mathrm{Bf}$ & 80 & 80 & 77 & 71 & 83 & 81 & 73 & 74 & 77 & 74 & .80 & 78 & 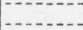 & 81 & $\begin{array}{l}80 \\
89\end{array}$ & 90 & 84 & 82 \\
\hline & $\begin{array}{c}28 \\
7\end{array}$ & Af & & 80 & $\begin{array}{l}77 \\
65\end{array}$ & 73 & 82 & 81 & 74 & 73 & 71 & 71 & 82 & 80 & $\ldots$ & 82 & 92 & 95 & 87 & 79 \\
\hline & 7 & Af & $\begin{array}{l}60 \\
63\end{array}$ & $\begin{array}{l}64 \\
66\end{array}$ & $\begin{array}{l}65 \\
65\end{array}$ & $\begin{array}{l}65 \\
62\end{array}$ & $\begin{array}{l}66 \\
69\end{array}$ & $\begin{array}{l}67 \\
63\end{array}$ & $\begin{array}{l}65 \\
66\end{array}$ & $\begin{array}{l}63 \\
63\end{array}$ & $\begin{array}{l}58 \\
53\end{array}$ & $\begin{array}{l}49 \\
52\end{array}$ & $\begin{array}{l}67 \\
66\end{array}$ & 69 & . & 71 & 58 & 67 & 61 & 69 \\
\hline \multirow{3}{*}{5} & 28 & $\mathrm{Bf}$ & 68 & 71 & 69 & 69 & 77 & 73 & 67 & $\begin{array}{l}05 \\
67\end{array}$ & $\begin{array}{l}53 \\
70\end{array}$ & $\begin{array}{l}52 \\
70\end{array}$ & $\begin{array}{l}66 \\
82\end{array}$ & $\begin{array}{l}67 \\
80\end{array}$ & & $\begin{array}{l}73 \\
86\end{array}$ & $\begin{array}{l}62 \\
78\end{array}$ & $\begin{array}{l}67 \\
78\end{array}$ & $\begin{array}{l}65 \\
76\end{array}$ & $\begin{array}{l}65 \\
79\end{array}$ \\
\hline & 28 & Af & 70 & 72 & 72 & 70 & 74 & 75 & 67 & 66 & 62 & 73 & 78 & 82 & & 87 & 80 & 0 & .83 & 83 \\
\hline & 7 & $\mathrm{Bf}$ & 53 & 52 & 60 & 59 & 63 & 64 & 66 & 63 & 45 & 52 & 67 & 66 & & 71 & 74 & 71 & 67 & 69 \\
\hline \multirow{4}{*}{$6 \ldots$} & 7 & Af & 59 & 55 & 57 & 54 & 59 & 68 & 64 & 62 & 48 & 52 & 68 & 65 & 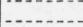 & 72 & 77 & 77 & 70 & 71 \\
\hline & $\begin{array}{l}28 \\
28\end{array}$ & $\mathrm{Bf}$ & 74 & 70 & 64 & $\begin{array}{l}68 \\
68\end{array}$ & 78 & 81 & 70 & 74 & 67 & 65 & 77 & 72 & . & 79 & 82 & 81 & 79 & 73 \\
\hline & $\begin{array}{r}28 \\
7\end{array}$ & $\begin{array}{l}\text { Af } \\
\text { Bf }\end{array}$ & $\begin{array}{l}76 \\
79\end{array}$ & $\begin{array}{l}73 \\
82\end{array}$ & $\begin{array}{l}66 \\
83\end{array}$ & $\begin{array}{l}68 \\
81\end{array}$ & $\begin{array}{l}81 \\
78\end{array}$ & $\begin{array}{l}82 \\
82\end{array}$ & $\begin{array}{l}72 \\
71\end{array}$ & $\begin{array}{l}71 \\
70\end{array}$ & $\begin{array}{l}66 \\
77\end{array}$ & $\begin{array}{l}68 \\
80\end{array}$ & $\begin{array}{l}79 \\
79\end{array}$ & $\begin{array}{l}76 \\
85\end{array}$ & $\ldots$ & 79 & 83 & 88 & 79 & 75 \\
\hline & 7 & Af & 86 & 82 & 82 & $\begin{array}{l}71 \\
79\end{array}$ & 81 & 81 & 71 & 69 & 84 & 82 & 70 & $\begin{array}{l}85 \\
76\end{array}$ & - & & $\begin{array}{l}83 \\
82\end{array}$ & 88 & 77 & $\begin{array}{l}83 \\
84\end{array}$ \\
\hline \multirow{3}{*}{7} & 28 & $\mathrm{Bf}$ & 89 & 92 & 90 & 92 & 97 & 96 & 89 & 87 & 96 & 92 & 92 & 92 & -- & & $\begin{array}{l}92 \\
99\end{array}$ & $\begin{array}{l}00 \\
94\end{array}$ & 96 & 97 \\
\hline & 28 & Af & 88 & 94 & 88 & 91 & 97 & 97 & 91 & 85 & 97 & 95 & 98 & 97 & 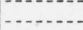 & & 98 & 9 & 6 & 97 \\
\hline & & $\mathrm{Bf}$ & 61 & 62 & 60 & 57 & 54 & 63 & 64 & 68 & 49 & 55 & 68 & 60 & $\ldots$ & 77 & 71 & 6 & 60 & 61 \\
\hline \multirow{3}{*}{8} & & Af & 67 & 60 & 58 & 59 & 62 & 65 & 61 & 67 & 47 & 55 & 66 & 60 & $\ldots$ & 74 & 69 & 6 ? & 59 & 62 \\
\hline & 28 & $\mathrm{Bf}$ & 75 & 76 & 75 & 71 & 76 & 73 & 78 & 78 & 71 & 70 & 80 & 77 & & 87 & 90 & 8 & 78 & 72 \\
\hline & 28 & Af & 76 & $\begin{array}{l}77 \\
54\end{array}$ & 72 & $\begin{array}{l}69 \\
65\end{array}$ & 78 & 77 & 79 & $\begin{array}{l}77 \\
64\end{array}$ & $\begin{array}{l}75 \\
50\end{array}$ & 72 & 82 & 77 & -7 & 87 & 93 & 5 & 78 & 80 \\
\hline \multirow{4}{*}{9} & 7 & $\begin{array}{l}\text { Bf } \\
\text { Af }\end{array}$ & $\begin{array}{l}57 \\
55\end{array}$ & $\begin{array}{l}54 \\
55\end{array}$ & $\begin{array}{l}60 \\
63\end{array}$ & $\begin{array}{l}65 \\
64\end{array}$ & $\begin{array}{l}50 \\
57\end{array}$ & $\begin{array}{l}56 \\
55\end{array}$ & $\begin{array}{l}66 \\
60\end{array}$ & $\begin{array}{l}64 \\
63\end{array}$ & $\begin{array}{l}50 \\
48\end{array}$ & $\begin{array}{l}48 \\
49\end{array}$ & $\begin{array}{l}63 \\
63\end{array}$ & $\begin{array}{l}60 \\
61\end{array}$ & 78 & $\begin{array}{l}75 \\
74\end{array}$ & $\begin{array}{l}66 \\
68\end{array}$ & $\begin{array}{l}57 \\
63\end{array}$ & $\begin{array}{l}54 \\
57\end{array}$ & $\begin{array}{l}58 \\
60\end{array}$ \\
\hline & 28 & $\mathrm{Bf}$ & 74 & 71 & 72 & 69 & 81 & 80 & 70 & 72 & 69 & 68 & 77 & 80 & 84 & 82 & 85 & 8 & 78 & 81 \\
\hline & 28 & $\overline{\mathrm{Af}}$ & 74 & 74 & 72 & 73 & 79 & 84 & 72 & 71 & 69 & 70 & 77 & 79 & & 82 & 83 & 8 & 81 & 81 \\
\hline & 7 & $\mathrm{Bf}$ & 41 & 43 & 45 & 45 & 37 & 45 & 53 & 56 & 41 & 46 & 45 & 49 & 61 & 65 & 60 & 58 & 52 & 53 \\
\hline 10 & $\begin{array}{r}7 \\
28\end{array}$ & Af & 45 & 45 & 46 & $\begin{array}{l}49 \\
59\end{array}$ & 42 & 46 & 54 & 52 & 39 & 40 & 50 & 53 & & 66 & 60 & 58 & 50 & 51 \\
\hline & $\begin{array}{l}28 \\
28\end{array}$ & $\begin{array}{l}\mathrm{Bf} \\
\mathrm{Af}\end{array}$ & $\begin{array}{l}61 \\
64\end{array}$ & $\begin{array}{l}60 \\
63\end{array}$ & $\begin{array}{l}61 \\
61\end{array}$ & $\begin{array}{l}59 \\
61\end{array}$ & $\begin{array}{l}62 \\
62\end{array}$ & $\begin{array}{l}62 \\
66\end{array}$ & $\begin{array}{l}65 \\
65\end{array}$ & $\begin{array}{l}67 \\
63\end{array}$ & $\begin{array}{l}60 \\
57\end{array}$ & $\begin{array}{l}59 \\
61\end{array}$ & $\begin{array}{l}65 \\
65\end{array}$ & $\begin{array}{l}66 \\
\mathbf{6 4}\end{array}$ & 76 & $\begin{array}{l}77 \\
77\end{array}$ & $\begin{array}{l}72 \\
75\end{array}$ & $\begin{array}{l}75 \\
75\end{array}$ & $\begin{array}{l}72 \\
70\end{array}$ & $\begin{array}{l}70 \\
70\end{array}$ \\
\hline
\end{tabular}




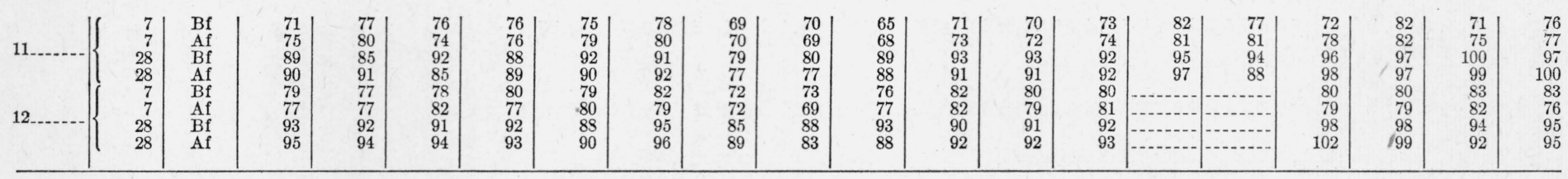

- $\mathrm{Bf}=$ Before filtration. $\mathrm{Af}=$ After filtration. 
TABLE 6.-Heats of hydration of cement clinker pastes with and without added materials.a

\begin{tabular}{|c|c|c|c|c|c|c|c|c|c|c|}
\hline Clinker & $\begin{array}{c}\text { Age of } \\
\text { hydrat- } \\
\text { ing } \\
\text { paste }\end{array}$ & $\begin{array}{l}\text { No ad- } \\
\text { dition }\end{array}$ & $\begin{array}{l}\text { Gyp- } \\
\text { sum }\end{array}$ & Sugar & $\begin{array}{l}\text { Cal- } \\
\text { cium } \\
\text { chlo- } \\
\text { ride }\end{array}$ & TDA & $\begin{array}{c}\text { Tannic } \\
\text { acid }\end{array}$ & $\begin{array}{c}\text { Tri- } \\
\text { ethanol- } \\
\text { amine }\end{array}$ & $\begin{array}{c}\text { Cal- } \\
\text { cium } \\
\text { acetate }\end{array}$ & $\begin{array}{l}\text { Fluo- } \\
\text { silicic } \\
\text { acid }\end{array}$ \\
\hline & & $\mathrm{cal} / g_{9}$ & $\mathrm{cal} / \mathrm{g}$ & $\mathrm{cal} / \mathrm{g}_{6}$ & $\mathrm{cal} / \mathrm{g}$ & $\mathrm{cal} / \mathrm{g}$ & $\mathrm{cal} / \mathrm{g}_{6}$ & callg & $\mathrm{cal} / \mathrm{g}$ & $\mathrm{cal} / \mathrm{g}$ \\
\hline & & 27 & 38 & 8 & 51 & $\begin{array}{r}8 \\
26\end{array}$ & $\begin{array}{r}0 \\
10\end{array}$ & $\begin{array}{l}20 \\
43\end{array}$ & $\begin{array}{r}8 \\
26\end{array}$ & 8 \\
\hline $1 \ldots$ & & 49 & 49 & 49 & 67 & 48 & 47 & 70 & 59 & 58 \\
\hline & 28 & 72 & 73 & 74 & 76 & 73 & 67 & 81 & 87 & 74 \\
\hline & & 24 & 19 & 25 & 31 & 26 & 8 & 28 & 24 & 25 \\
\hline $2 \ldots$ & & $\begin{array}{l}38 \\
45\end{array}$ & $\begin{array}{l}31 \\
42\end{array}$ & $\begin{array}{l}38 \\
48\end{array}$ & $\begin{array}{l}39 \\
41\end{array}$ & $\begin{array}{l}39 \\
46\end{array}$ & $\begin{array}{l}32 \\
41\end{array}$ & $\begin{array}{l}41 \\
52\end{array}$ & $\begin{array}{l}41 \\
50\end{array}$ & $\begin{array}{l}36 \\
60\end{array}$ \\
\hline & & 56 & 58 & 65 & 55 & 66 & 68 & 72 & 69 & 64 \\
\hline & $1 / 2$ & 36 & 60 & 14 & 63 & 17 & 11 & 56 & 38 & 15 \\
\hline 3. & & 68 & 72 & 63 & 65 & 86 & 24 & $\begin{array}{l}61 \\
03\end{array}$ & 67 & 24 \\
\hline & 28 & $\begin{array}{r}82 \\
105\end{array}$ & $\begin{array}{r}82 \\
107\end{array}$ & $\begin{array}{l}84 \\
92\end{array}$ & $\begin{array}{l}80 \\
91\end{array}$ & $\begin{array}{l}70 \\
99\end{array}$ & 97 & $\begin{array}{r}90 \\
103\end{array}$ & $\begin{array}{r}92 \\
105\end{array}$ & $\begin{array}{r}84 \\
102\end{array}$ \\
\hline & & 48 & 58 & 50 & 57 & 57 & 47 & 58 & 56 & 16 \\
\hline 4... & & 53 & 64 & 59 & 63 & 61 & 66 & 64 & 66 & 61 \\
\hline & 28 & $\begin{array}{l}70 \\
80\end{array}$ & $\begin{array}{l}67 \\
77\end{array}$ & $\begin{array}{l}79 \\
83\end{array}$ & $\begin{array}{l}62 \\
73\end{array}$ & $\begin{array}{l}71 \\
77\end{array}$ & $\begin{array}{l}75 \\
80\end{array}$ & --- & $\begin{array}{l}83 \\
89\end{array}$ & $\begin{array}{l}78 \\
84\end{array}$ \\
\hline & 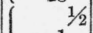 & 38 & 41 & 20 & 48 & 42 & 30 & 14 & 10 & 9 \\
\hline 5 & & 54 & 69 & 48 & 59 & $\begin{array}{l}56 \\
58\end{array}$ & $\begin{array}{l}44 \\
67\end{array}$ & 32 & $\begin{array}{l}35 \\
58\end{array}$ & 13 \\
\hline & 28 & $\begin{array}{l}60 \\
68\end{array}$ & $\begin{array}{l}60 \\
69\end{array}$ & $\begin{array}{l}\text { bo } \\
77\end{array}$ & $\begin{array}{l}65 \\
67\end{array}$ & $\begin{array}{l}08 \\
70\end{array}$ & 82 & & $\begin{array}{l}58 \\
78\end{array}$ & $\begin{array}{l}61 \\
76\end{array}$ \\
\hline & $1 / 2$ & 35 & 48 & 46 & 58 & 42 & 11 & 52 & 25 & 13 \\
\hline 6. & & 48 & 62 & 63 & 65 & 56 & 58 & 67 & 70 & 58 \\
\hline & & 53 & 60 & 63 & 66 & 45 & 67 & .......... & 74 & $\begin{array}{l}67 \\
70\end{array}$ \\
\hline & & $\begin{array}{l}74 \\
34\end{array}$ & $\begin{array}{l}64 \\
60\end{array}$ & 37 & 58 & $\begin{array}{l}67 \\
53\end{array}$ & $\begin{array}{l}77 \\
21\end{array}$ & 61 & $\begin{array}{l}82 \\
41\end{array}$ & $\begin{array}{l}79 \\
23\end{array}$ \\
\hline & & 69 & 72 & 68 & 66 & 70 & 33 & 70 & 70 & 47 \\
\hline & 7 & 79 & 83 & 78 & 71 & 77 & 79 & $\cdots$ & 83 & 75 \\
\hline & 28 & 89 & 90 & 97 & 89 & 96 & 92 & & 99 & 96 \\
\hline & 1 & 21 & 35 & 15 & 51 & 16 & 12 & 57 & 11 & 14 \\
\hline 8.. & $\begin{array}{l}1 \\
7\end{array}$ & $\begin{array}{l}49 \\
61\end{array}$ & $\begin{array}{l}58 \\
60\end{array}$ & $\begin{array}{l}45 \\
54\end{array}$ & $\begin{array}{l}64 \\
64\end{array}$ & $\begin{array}{l}38 \\
49\end{array}$ & 16 & 67 & 20 & 16 \\
\hline & 28 & 75 & 75 & 76 & 78 & 71 & 80 & & 90 & $\begin{array}{l}60 \\
78\end{array}$ \\
\hline & $1 / 2$ & 24 & 35 & 11 & 51 & 14 & 9 & 60 & 9 & 12 \\
\hline & & 45 & 61 & 24 & 63 & 53 & 16 & 68 & 13 & 13 \\
\hline & & 57 & 60 & 50 & 66 & 50 & 63 & 78 & 66 & 54 \\
\hline & 28 & 74 & 72 & 81 & 70 & 69 & 77 & 84 & 85 & 78 \\
\hline & & 16 & 23 & 6 & 41 & 15 & 6 & 16 & 8 & 8 \\
\hline 10 & & 28 & 36 & 8 & 52 & 33 & 8 & 29 & 11 & 16 \\
\hline & $\begin{array}{r}7 \\
28\end{array}$ & $\begin{array}{l}41 \\
61\end{array}$ & $\begin{array}{l}45 \\
61\end{array}$ & $\begin{array}{l}37 \\
62\end{array}$ & $\begin{array}{l}53 \\
65\end{array}$ & $\begin{array}{l}41 \\
60\end{array}$ & $\begin{array}{l}45 \\
65\end{array}$ & $\begin{array}{l}61 \\
76\end{array}$ & $\begin{array}{l}60 \\
72\end{array}$ & $\begin{array}{l}52 \\
72\end{array}$ \\
\hline & & 15 & 60 & 21 & 60 & 19 & 14 & 32 & 13 & 18 \\
\hline 11. & $\frac{1}{7}$ & 48 & 68 & 66 & 68 & 62 & 19 & 72 & 54 & 35 \\
\hline & $\begin{array}{r}7 \\
28\end{array}$ & $\begin{array}{l}71 \\
89\end{array}$ & $\begin{array}{l}76 \\
92\end{array}$ & $\begin{array}{l}75 \\
92\end{array}$ & $\begin{array}{l}69 \\
79\end{array}$ & $\begin{array}{l}65 \\
89\end{array}$ & $\begin{array}{l}70 \\
93\end{array}$ & $\begin{array}{l}82 \\
95\end{array}$ & $\begin{array}{l}72 \\
96\end{array}$ & $\begin{array}{r}71 \\
100\end{array}$ \\
\hline & & 23 & 60 & 38 & 60 & $\begin{array}{l}89 \\
32\end{array}$ & 19 & 62 & 16 & 20 \\
\hline 12 & 1 & 63 & 68 & 73 & 69 & 69 & 42 & 68 & 37 & 53 \\
\hline & 7 & 79 & 78 & 79 & 72 & 76 & 80 & $\cdots$ & 80 & 33 \\
\hline & 28 & 93 & 91 & 88 & 85 & 93 & 91 & & 98 & 94 \\
\hline
\end{tabular}

aThe $1 / 2-$ and 1-day heats of hydration were determined by integrating the time-temperature curves. The 7- and 28-day heats of hydration are those determined by the heat-of-solution method, using the 7min. pastes before filtration.

Calcium chloride increased the heats of hydration at $1 / 2$ day, usually by even larger amounts than did gypsum. At 1 day, three-fourths of the heats of hydration were increased and none were decreased. At 7 days the increases were more frequent and somewhat larger than the decreases, whereas at 28 days half of the heats of hydration were decreased by calcium chloride by an average of 8 percent.

TDA tended to increase the heats of hydration at the early ages and to leave them unchanged or to decrease them later. With a few exceptions the changes were not large.

Tannic acid reduced nearly all the heats of hydration at $1 / 2$ and 1 day, whereas at 7 and 28 days most of the heats were unchanged or increased. The decreases were frequently rather large, whereas the increases seldom exceeded 25 percent. 
TABLE 7.-Heats of hydration of cement clinker pastes containing added materials as percentages of the heats of hydration of the pastes without addition a

\begin{tabular}{|c|c|c|c|c|c|c|c|c|c|}
\hline Clinker & $\begin{array}{c}\text { Age of } \\
\text { hydrat- } \\
\text { ing paste }\end{array}$ & Gypsum & Sugar & $\begin{array}{l}\text { Calcium } \\
\text { chloride }\end{array}$ & TDA & $\begin{array}{l}\text { Tannic } \\
\text { acid }\end{array}$ & $\begin{array}{l}\text { Triethan- } \\
\text { olamine }\end{array}$ & $\begin{array}{l}\text { Calcium } \\
\text { acetate }\end{array}$ & $\begin{array}{l}\text { Fluo- } \\
\text { silicic } \\
\text { acid }\end{array}$ \\
\hline \multirow{5}{*}{1.} & Day & & $\%$ & & $\%$ & $\%$ & $\%$ & $\%$ & $\%$ \\
\hline & & 178 & 67 & 434 & & 111 & 222 & & 68 \\
\hline & & $\begin{array}{l}141 \\
100\end{array}$ & $\begin{array}{r}30 \\
100\end{array}$ & $\begin{array}{l}189 \\
136\end{array}$ & $\begin{array}{l}96 \\
98\end{array}$ & $\begin{array}{l}37 \\
96\end{array}$ & $\begin{array}{l}159 \\
143\end{array}$ & $\begin{array}{r}96 \\
120\end{array}$ & $\begin{array}{r}30 \\
118\end{array}$ \\
\hline & 28 & 101 & 103 & 106 & 101 & 93 & 112 & 121 & 103 \\
\hline & $1 / 2$ & 79 & 104 & 129 & 108 & 33 & 117 & 100 & 104 \\
\hline \multirow{4}{*}{2} & & 82 & 100 & 103 & 103 & 84 & 108 & 108 & 95 \\
\hline & 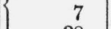 & 93 & 107 & 91 & 102 & 91 & 116 & 111 & 133 \\
\hline & 8 & 103 & 116 & 98 & 118 & 121 & 128 & 123 & 114 \\
\hline & $1 / 2$ & 167 & 39 & 175 & 47 & 31 & 156 & 105 & 42 \\
\hline \multirow{4}{*}{$3 \ldots$} & 1 & 106 & 93 & 96 & 127 & 35 & 90 & 99 & 35 \\
\hline & 7 & 100 & 102 & 98 & 93 & 95 & 113 & 112 & 102 \\
\hline & 28 & 102 & 88 & 87 & 94 & 92 & 99 & 100 & 97 \\
\hline & & 121 & 104 & 119 & 119 & 98 & 121 & 117 & 33 \\
\hline \multirow{4}{*}{4} & & 121 & 111 & 119 & 115 & 124 & 121 & 124 & 115 \\
\hline & 7 & 96 & 113 & 89 & 102 & 107 & & 119 & 111 \\
\hline & 28 & 96 & 104 & 91 & 96 & 100 & & 111 & 105 \\
\hline & & 108 & 53 & 126 & 111 & 79 & 37 & 26 & 24 \\
\hline \multirow{4}{*}{5} & & 128 & 89 & 110 & 104 & 82 & 59 & 65 & 24 \\
\hline & 7 & 108 & 110 & 108 & 97 & 112 & & 97 & 102 \\
\hline & & 102 & 113 & 99 & 103 & 121 & & 115 & 112 \\
\hline & & 137 & 131 & 166 & 120 & 31 & 159 & 72 & 37 \\
\hline \multirow{4}{*}{6} & & 129 & 131 & 136 & 117 & 121 & 140 & 146 & 121 \\
\hline & 7 & 113 & 119 & 125 & 85 & 126 & & 140 & 128 \\
\hline & 8 & 87 & 105 & 95 & 90 & 104 & 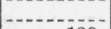 & 111 & 107 \\
\hline & $1 / 2$ & 177 & 109 & 171 & 156 & 62 & 180 & 121 & 68 \\
\hline \multirow{5}{*}{7} & 1 & 104 & 99 & 96 & 102 & 48 & 101 & 101 & 68 \\
\hline & 7 & 105 & 99 & 90 & 98 & 100 & & 105 & 95 \\
\hline & 28 & 101 & 109 & 100 & 108 & 103 & & 111 & 108 \\
\hline & $1 / 2$ & 166 & 71 & 243 & 76 & 57 & 271 & 52 & 67 \\
\hline & 1 & 118 & 92 & 130 & 78 & 33 & 137 & 41 & 33 \\
\hline \multirow{4}{*}{8} & & 98 & 89 & 105 & 80 & 111 & & 117 & 98 \\
\hline & 28 & 100 & 101 & 104 & 95 & 107 & & 120 & 104 \\
\hline & $1 / 2$ & 141 & 46 & 212 & 58 & 38 & 250 & 38 & 50 \\
\hline & 1 & 136 & 53 & 140 & 118 & 36 & 151 & 29 & 29 \\
\hline \multirow{4}{*}{$9 \ldots$} & 7 & 105 & 88 & 116 & 88 & 110 & 137 & 116 & 95 \\
\hline & 28 & 97 & 109 & 95 & 93 & 104 & 114 & 115 & 105 \\
\hline & $1 / 2$ & 144 & 38 & 256 & 94 & 38 & 100 & 50 & 50 \\
\hline & 1 & 129 & 29 & 186 & 118 & 29 & 104 & 39 & 57 \\
\hline \multirow[t]{3}{*}{$10 \ldots$} & 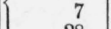 & 110 & 90 & 129 & 100 & 110 & 149 & 146 & 127 \\
\hline & 28 & 100 & 102 & 107 & 98 & 107 & 125 & 118 & 118 \\
\hline & . & 400 & 140 & 400 & 127 & 93 & 213 & 86 & 120 \\
\hline \multirow{4}{*}{11} & 1 & 142 & 137 & 142 & 129 & 40 & 150 & 113 & 73 \\
\hline & 7 & 107 & 106 & 97 & 92 & 99 & 116 & 102 & 100 \\
\hline & 28 & 103 & 103 & 89 & 100 & 104 & 107 & 108 & 112 \\
\hline & $1 / 2$ & 261 & 165 & 261 & 139 & 82 & 27 & 70 & 87 \\
\hline \multirow{3}{*}{12} & 1 & 108 & 116 & 110 & 110 & 67 & 108 & 59 & 84 \\
\hline & 7 & 99 & 100 & 91 & 96 & 101 & .... & 101 & 105 \\
\hline & 28 & 98 & 95 & 91 & 100 & 98 & $\cdots$ & 105 & 101 \\
\hline
\end{tabular}

F a The 1/2- and 1-day heats of hydration were determined by integrating the temperature-time curves. The 7- and 28-day heats of hydration were determined by the heat-of-solution method, using the 7-min. pastes before filtration.

Triethanolamine increased most of the heats of hydration at all ages for which data were available. In several instances pastes containing triethanolamine hardened so rapidly that all tests were not performed. The few decreases in the heats of hydration that occurred were usually rather large.

W Calcium acetate and fluosilicic acid decreased the majority of the heats of hydration at $1 / 2$ and 1 day and increased them at 7 and 28 days. In general, the decreases were larger than the increases.

W. It may be noted that the effects of these substances were frequently large and variable during the first $24 \mathrm{hr}$, but that by 7 days most of the changes were small. At the end of 28 days very many of the heats of hydration were not affected significantly. 


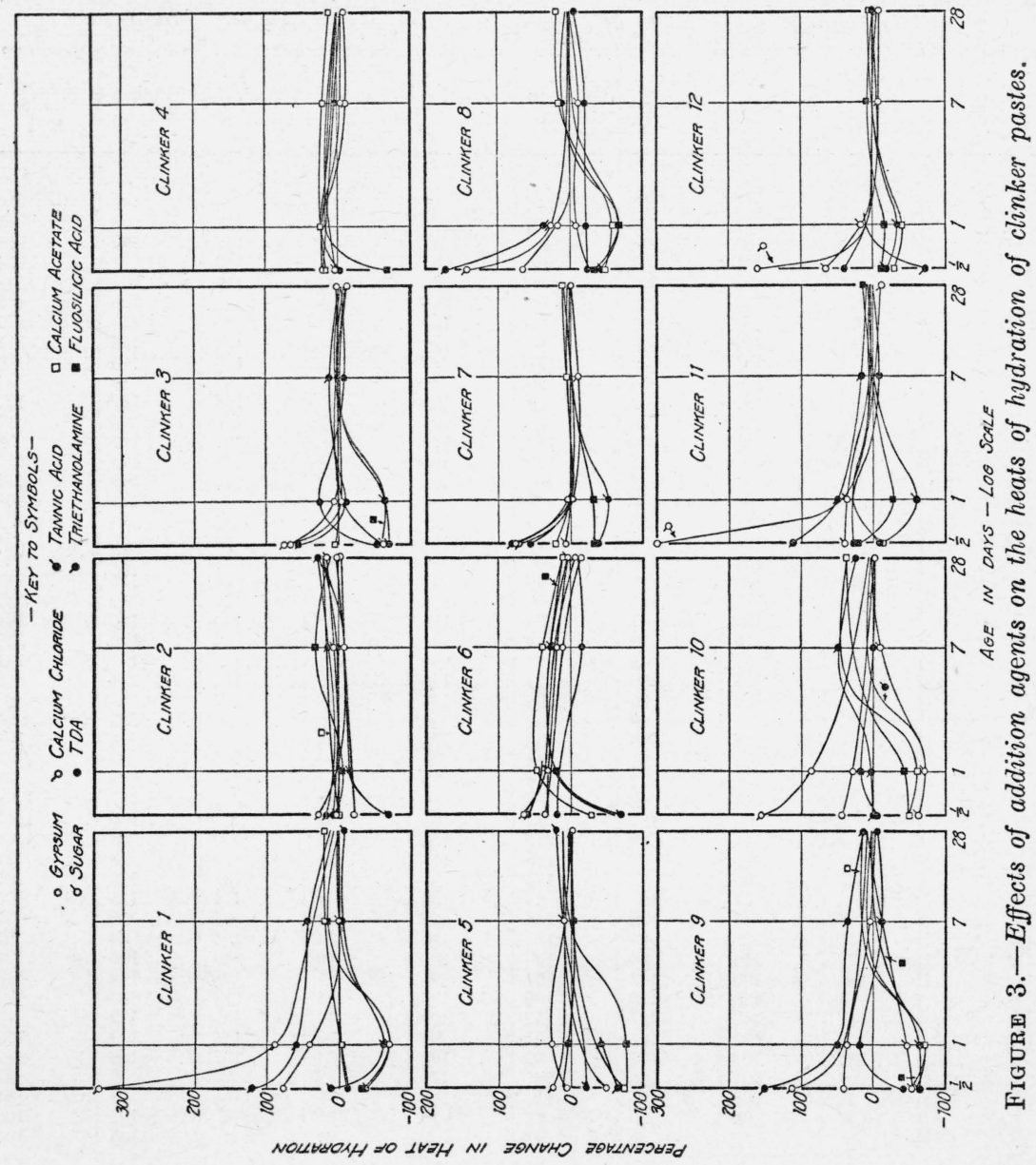

\section{STRENGTHS}

The results of the strength tests are presented in table 8. Because the $2 \frac{1}{2}-\mathrm{hr}$ pastes were frequently rather stiff, many of the specimens could not be fabricated properly. For this reason the strengths of the $1 / 2-\mathrm{hr}$ pastes are the more reliable. The strengths of the specimens made from the $1 / 2-\mathrm{hr}$ pastes were calculated as percentages of the strengths of the test pieces containing no added material and are presented in table 8 . Few of the pastes containing triethanolamine were workable, and the strengths of specimens containing it are omitted from table 8 and from the discussion.

It should be pointed out that the strength specimens were fabricated from pastes from which part of the added substance had been removed by filtration. Therefore, the amount originally added was not that present during the hardening of the specimens. However, the analyses of the extracted liquids, together with their volumes compared with the amount of water originally added [1], indicated that a large part of the addition remained in the paste. 
TABLE 8.-Strengths of specimens fabricated from filtered a pastes with and without additions

\begin{tabular}{|c|c|c|c|c|c|c|c|c|c|c|c|c|c|c|c|c|c|c|c|c|c|c|c|c|c|}
\hline \multirow{3}{*}{ Clinker } & \multirow[b]{3}{*}{4} & \multirow{3}{*}{ 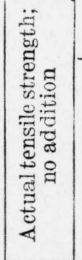 } & \multicolumn{7}{|c|}{ Relative tensile strength $\mathrm{b}$} & \multirow{2}{*}{\multicolumn{2}{|c|}{\begin{tabular}{|c|} 
Actual \\
compressive \\
strength; no \\
addition
\end{tabular}}} & \multicolumn{14}{|c|}{ Relative compressive strength $b$} \\
\hline & & & \multirow[b]{2}{*}{$\begin{array}{l}\text { 貝 } \\
\text { 总 } \\
\text { हु }\end{array}$} & \multirow[b]{2}{*}{ 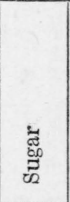 } & \multirow{2}{*}{ 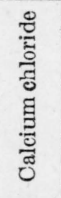 } & \multirow[b]{2}{*}{$\stackrel{\leftrightarrow}{\mathrm{H}}$} & \multirow[b]{2}{*}{ 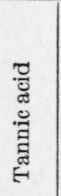 } & \multirow{2}{*}{ 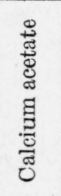 } & \multirow{2}{*}{ 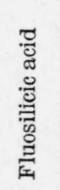 } & & & \multicolumn{2}{|c|}{ Gypsum } & \multicolumn{2}{|c|}{ Sugar } & \multicolumn{2}{|c|}{$\begin{array}{l}\text { Calcium } \\
\text { chloride }\end{array}$} & \multicolumn{2}{|c|}{ TDA } & \multicolumn{2}{|c|}{$\underset{\text { acid }}{\text { Tannic }}$} & \multicolumn{2}{|c|}{$\begin{array}{l}\text { Calcium } \\
\text { acetate }\end{array}$} & \multicolumn{2}{|c|}{$\begin{array}{c}\text { Fluosilicic } \\
\text { acid }\end{array}$} \\
\hline & & & & & & & & & & 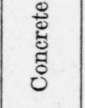 & 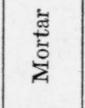 & 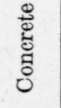 & 营 & 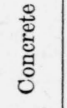 & 营 & 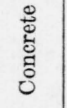 & 焉 & 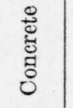 & 营 & 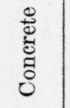 & 营 & 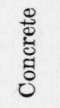 & 营 & 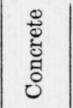 & 焉 \\
\hline \multirow{5}{*}{$1 \ldots$} & Days & Ub/in ${ }^{2}$ & $\begin{array}{c}\% \\
(45) c\end{array}$ & $\%_{(0)}$ & $\begin{array}{l}\% \\
(90)\end{array}$ & $\%_{(0)}$ & $\%$ & $\%$ & $\%$ & Lb/in: & lb/in? & 60 & $\%$ & $\%$ & $\%$ & 70 & & $\%$ & & $\%$ & & & & & \\
\hline & 3 & $\begin{array}{l}110 \\
205\end{array}$ & $\begin{array}{l}150 \\
150\end{array}$ & 50 & 240 & $\begin{array}{r}100 \\
100\end{array}$ & 50 & 220 & 60 & \begin{tabular}{|r|}
40 \\
470 \\
\end{tabular} & \begin{tabular}{|r|} 
\\
000 \\
\end{tabular} & $\begin{array}{l}600 \\
180\end{array}$ & $\begin{array}{l}360 \\
150\end{array}$ & $\begin{array}{r}0 \\
50\end{array}$ & $\begin{array}{r}0 \\
50\end{array}$ & $\begin{array}{l}700 \\
240\end{array}$ & $\begin{array}{l}950 \\
270\end{array}$ & $\begin{array}{r}80 \\
100\end{array}$ & $\begin{array}{l}50 \\
80\end{array}$ & $\begin{array}{l}0 \\
90\end{array}$ & $\begin{array}{l}0 \\
70\end{array}$ & $\begin{array}{l}330 \\
230\end{array}$ & $\begin{array}{l}0 \\
0 \\
0\end{array}$ & $\begin{array}{r}0 \\
50\end{array}$ & $\begin{array}{r}0 \\
40\end{array}$ \\
\hline & 28 & $\begin{array}{l}255 \\
375\end{array}$ & $\begin{array}{l}120 \\
110\end{array}$ & $\begin{array}{r}90 \\
110\end{array}$ & $\begin{array}{l}130 \\
110\end{array}$ & $\begin{array}{r}90 \\
100\end{array}$ & $\begin{array}{r}80 \\
100\end{array}$ & $\begin{array}{l}130 \\
110\end{array}$ & $\begin{array}{l}100 \\
110\end{array}$ & $\mid$\begin{tabular}{|}
1,340 \\
0
\end{tabular} & \begin{tabular}{|l|}
2,380 \\
\end{tabular} & 110 & 100 & 80 & $\begin{array}{r}90 \\
\end{array}$ & 130 & 170 & 110 & 90 & 100 & 90 & 150 & 170 & 90 & $\begin{array}{r}40 \\
100\end{array}$ \\
\hline & & 50 & 180 & 16 & 240 & 200 & 90 & & 140 & 250 & 4, & 11 & $\begin{array}{r}90 \\
140\end{array}$ & $\begin{array}{r}100 \\
80\end{array}$ & 110 & 14 & $\begin{array}{l}180 \\
180\end{array}$ & $\begin{array}{r}90 \\
110\end{array}$ & $\begin{array}{c}90 \\
130\end{array}$ & $\begin{array}{r}100 \\
60\end{array}$ & $\begin{array}{r}100 \\
60\end{array}$ & 10 & & $\begin{array}{r}110 \\
80\end{array}$ & 110 \\
\hline & $\begin{array}{l}3 \\
7\end{array}$ & $\begin{array}{l}170 \\
280\end{array}$ & $\begin{array}{l}120 \\
100\end{array}$ & $\begin{array}{l}120 \\
110\end{array}$ & $\begin{array}{l}120 \\
110\end{array}$ & $\begin{array}{l}120 \\
110\end{array}$ & $\begin{array}{l}90 \\
80\end{array}$ & $\begin{array}{r}110 \\
90\end{array}$ & $\begin{array}{l}130 \\
110\end{array}$ & $\begin{array}{r}640 \\
\end{array}$ & $\begin{array}{l}1,22 \\
2,20\end{array}$ & $\begin{array}{l}120 \\
100\end{array}$ & $\begin{array}{l}150 \\
140\end{array}$ & $\begin{array}{l}120 \\
130\end{array}$ & $\begin{array}{l}160 \\
160\end{array}$ & 120 & $\begin{array}{l}150 \\
150\end{array}$ & 120 & $\begin{array}{l}140 \\
150\end{array}$ & $\begin{array}{l}110 \\
110\end{array}$ & 110 & 120 & 160 & 130 & 160 \\
\hline \multirow{4}{*}{3} & 28 & 355 & 140 & $\begin{array}{l}100 \\
120\end{array}$ & $\begin{array}{l}110 \\
120\end{array}$ & $\begin{array}{l}110 \\
130\end{array}$ & $\begin{array}{r}80 \\
110\end{array}$ & , & $\begin{array}{l}110 \\
110\end{array}$ & $\begin{array}{l}1,210 \\
2,800\end{array}$ & $\begin{array}{l}2,2 \\
4,2\end{array}$ & & $\begin{array}{l}1 \\
1\end{array}$ & $\begin{array}{l}130 \\
120\end{array}$ & & & 1 & 0 & 50 & 10 & & & & & 170 \\
\hline & 1 & 125 & 160 & 0 & 230 & 110 & 0 & 120 & 0 & ${ }_{460}^{2}$ & & & & $\begin{array}{r}120 \\
0\end{array}$ & & 2 & & ${ }_{90}^{110}$ & $\begin{array}{r}140 \\
90\end{array}$ & $\begin{array}{l}110 \\
300\end{array}$ & & & & 0 & 150 \\
\hline & 3 & 345 & 110 & 100 & 100 & 110 & 80 & & 80 & 2,020 & 3 , & 10 & 80 & 90 & 00 & 11 & 10 & 90 & 90 & 80 & & 00 & & 0 & 80 \\
\hline & & $\begin{array}{l}440 \\
515\end{array}$ & $\begin{array}{l}110 \\
100\end{array}$ & ${ }_{11}^{10}$ & $\begin{array}{l}100 \\
90\end{array}$ & $\begin{array}{l}100 \\
100\end{array}$ & $\begin{array}{r}90 \\
\end{array}$ & 100 & 90 & & & 18 & 90 & 90 & & & 9 & 110 & & 100 & & & 70 & 90 & 00 \\
\hline & & $\begin{array}{l}515 \\
100\end{array}$ & $\begin{array}{l}100 \\
130\end{array}$ & $\begin{array}{r}100 \\
0\end{array}$ & $\begin{array}{r}90 \\
210\end{array}$ & $\begin{array}{r}100 \\
90\end{array}$ & $\begin{array}{r}100 \\
0\end{array}$ & $\begin{array}{l}90 \\
90\end{array}$ & $\begin{array}{r}90 \\
0\end{array}$ & 4, & & $\begin{array}{l}110 \\
130\end{array}$ & 90 & 00 & & & 86 & 110 & 100 & 100 & & 90 & & 50 & 10 \\
\hline & $\begin{array}{l}3 \\
7\end{array}$ & 230 & $\begin{array}{l}100 \\
120\end{array}$ & 120 & $\begin{array}{l}150 \\
150\end{array}$ & 70 & $\begin{array}{r}0 \\
110\end{array}$ & $\begin{array}{r}130 \\
130\end{array}$ & $\begin{array}{l}100 \\
\end{array}$ & \begin{tabular}{|r|}
450 \\
1,440 \\
\end{tabular} & \begin{tabular}{|r|}
650 \\
1,690
\end{tabular} & $\begin{array}{l}130 \\
100\end{array}$ & $\begin{array}{l}160 \\
160\end{array}$ & 90 & 30 & $\begin{array}{l}150 \\
110\end{array}$ & $\begin{array}{l}170 \\
140\end{array}$ & $\begin{array}{l}90 \\
90\end{array}$ & $\begin{array}{l}80 \\
80\end{array}$ & $\begin{array}{r}0 \\
80\end{array}$ & 120 & $\begin{array}{r}50 \\
100\end{array}$ & 90 & 0 & 0 \\
\hline & 7 & $\begin{array}{l}260 \\
345\end{array}$ & ${ }_{130}^{130}$ & 1 & 15 & $\begin{array}{l}100 \\
110\end{array}$ & 110 & $\begin{array}{l}130 \\
130\end{array}$ & 120 & 2,310 & 2,4 & 16 & 170 & 110 & J & 100 & 1 & 90 & 90 & 100 & 1 & $\begin{array}{l}100 \\
110\end{array}$ & 10 & 90 & $\begin{array}{l}110 \\
110\end{array}$ \\
\hline & 28 & $\begin{array}{r}340 \\
70\end{array}$ & $\begin{array}{l}2100 \\
210\end{array}$ & $\begin{array}{r}110 \\
0\end{array}$ & $\begin{array}{l}120 \\
250\end{array}$ & $\begin{array}{r}110 \\
80\end{array}$ & $\begin{array}{r}110 \\
0\end{array}$ & $\begin{array}{r}130 \\
60\end{array}$ & $\begin{array}{r}120 \\
0\end{array}$ & $\left|\begin{array}{|}3,610 \\
170\end{array}\right|$ & 3,4 & $\frac{1}{28}$ & 17 & 100 & 10 & $\begin{array}{r}90 \\
260\end{array}$ & 120 & 100 & 110 & 110 & 110 & 110 & 190 & 100 & 110 \\
\hline & 3 & 180 & $\begin{array}{l}150 \\
150\end{array}$ & 130 & $\begin{array}{l}250 \\
160\end{array}$ & $\begin{array}{l}80 \\
90\end{array}$ & 90 & $\begin{array}{r}60 \\
160\end{array}$ & $\begin{array}{r}0 \\
110\end{array}$ & $\begin{array}{l}170 \\
870\end{array}$ & \begin{tabular}{|r|}
500 \\
1,660
\end{tabular} & $\begin{array}{l}280 \\
130\end{array}$ & $\begin{array}{l}190 \\
130\end{array}$ & $\begin{array}{r}0 \\
100\end{array}$ & $\begin{array}{r}0 \\
120\end{array}$ & $\begin{array}{l}360 \\
170\end{array}$ & $\begin{array}{l}220 \\
160\end{array}$ & $\begin{array}{l}170 \\
110\end{array}$ & $\begin{array}{l}70 \\
60\end{array}$ & $\begin{array}{r}0 \\
100\end{array}$ & $\begin{array}{r}0 \\
60\end{array}$ & $\begin{array}{r}80 \\
120\end{array}$ & $\begin{array}{r}30 \\
150\end{array}$ & $\begin{array}{r}0 \\
50\end{array}$ & 80 \\
\hline & $\begin{array}{r}7 \\
28\end{array}$ & $\begin{array}{l}285 \\
255\end{array}$ & 120 & 1 & 140 & $\begin{array}{r}80 \\
100\end{array}$ & $\begin{array}{r}80 \\
\end{array}$ & 120 & 90 & 1.760 & 2,550 & 11 & 120 & 110 & 140 & 120 & 150 & 110 & 80 & 110 & 90 & 110 & 90 & 90 & 90 \\
\hline & 28 & $\begin{array}{r}355 \\
75\end{array}$ & $\begin{array}{l}130 \\
250\end{array}$ & $\begin{array}{r}120 \\
0\end{array}$ & $\begin{array}{l}120 \\
250\end{array}$ & $\begin{array}{r}100 \\
70\end{array}$ & $\begin{array}{r}110 \\
0\end{array}$ & $\begin{array}{l}130 \\
260\end{array}$ & $\begin{array}{r}90 \\
0\end{array}$ & $\left|\begin{array}{r}3,450 \\
300\end{array}\right|$ & 4,2 & ${ }_{20}^{10}$ & 1 & 100 & & 90 & 13 & 100 & 90 & 110 & & 110 & & 100 & 100 \\
\hline & & 155 & 190 & 160 & $\begin{array}{l}200 \\
190\end{array}$ & 80 & $\begin{array}{r}0 \\
130\end{array}$ & 210 & $\begin{array}{r}0 \\
140\end{array}$ & $\begin{array}{r}300 \\
1.210\end{array}$ & & $\begin{array}{l}220 \\
120\end{array}$ & 2 & $\begin{array}{r}0 \\
100\end{array}$ & & $\begin{array}{l}240 \\
150\end{array}$ & & 100 & $\begin{array}{l}80 \\
80\end{array}$ & $\begin{array}{r}0 \\
100\end{array}$ & & 160 & & 0 & \\
\hline & ${ }_{28}^{7}$ & 255 & 160 & 1. & 160 & 70 & & 180 & 120 & 2,130 & 2,2 & 100 & i & $\begin{array}{l}100 \\
120\end{array}$ & & $\begin{array}{l}100 \\
120\end{array}$ & 1 & 80 & 80 & $\begin{array}{l}100 \\
120\end{array}$ & $\begin{array}{l}11 \\
13\end{array}$ & $\begin{array}{l}140 \\
150\end{array}$ & 90 & $\begin{array}{r}75 \\
130\end{array}$ & 150 \\
\hline & 28 & $\begin{array}{r}380 \\
35\end{array}$ & $\begin{array}{l}130 \\
490\end{array}$ & $\begin{array}{r}110 \\
0\end{array}$ & $\begin{array}{l}120 \\
630\end{array}$ & $\begin{array}{l}90 \\
70\end{array}$ & $\begin{array}{r}100 \\
0\end{array}$ & $\begin{array}{r}120 \\
50\end{array}$ & $\begin{array}{r}110 \\
0\end{array}$ & $\begin{array}{r}3,460 \\
230\end{array}$ & $\begin{array}{r}3,810 \\
410\end{array}$ & $\begin{array}{l}120 \\
250\end{array}$ & $\begin{array}{l}150 \\
260\end{array}$ & $\begin{array}{r}120 \\
0\end{array}$ & 0 & $\begin{array}{l}100 \\
290\end{array}$ & $\begin{array}{l}150 \\
350\end{array}$ & $\begin{array}{l}80 \\
40\end{array}$ & $\begin{array}{l}90 \\
60\end{array}$ & 120 & 100 & 130 & 220 & 130 & 120 \\
\hline & 3 & $\begin{array}{l}200 \\
250\end{array}$ & $\begin{array}{l}150 \\
140\end{array}$ & $\begin{array}{r}100 \\
70\end{array}$ & $\begin{array}{l}150 \\
140\end{array}$ & $\begin{array}{l}110 \\
120\end{array}$ & $\begin{array}{l}80 \\
00\end{array}$ & $\begin{array}{r}90 \\
100\end{array}$ & $\begin{array}{l}80 \\
90\end{array}$ & 1,150 & $\begin{array}{r}1,380 \\
2,373\end{array}$ & $\begin{array}{l}120 \\
110\end{array}$ & $\begin{array}{l}190 \\
160\end{array}$ & 80 & 130 & $\begin{array}{l}200 \\
130\end{array}$ & 200 & $\begin{array}{l}80 \\
80\end{array}$ & $\begin{array}{r}130 \\
130\end{array}$ & 60 & 70 & $\begin{array}{r}70 \\
110\end{array}$ & $\begin{array}{r}00 \\
130\end{array}$ & 20 & 80 \\
\hline & 28 & 235 & $\begin{array}{l}1400 \\
180\end{array}$ & 130 & $\begin{array}{l}140 \\
190\end{array}$ & $\begin{array}{l}120 \\
180\end{array}$ & $\begin{array}{r}80 \\
120\end{array}$ & 140 & 130 & \begin{tabular}{|l}
2,240 \\
3,810
\end{tabular} & 2,990 & $\begin{array}{l}110 \\
110\end{array}$ & $\begin{array}{l}100 \\
200\end{array}$ & $\begin{array}{l}90 \\
90\end{array}$ & $\begin{array}{l}10 \\
10\end{array}$ & $\begin{array}{l}100 \\
90\end{array}$ & $\begin{array}{l}180 \\
180\end{array}$ & $\begin{array}{l}90 \\
90\end{array}$ & $\begin{array}{l}140 \\
160\end{array}$ & $\begin{array}{l}80 \\
80\end{array}$ & $\begin{array}{l}80 \\
90\end{array}$ & $\begin{array}{r}100 \\
80\end{array}$ & $\begin{array}{l}120 \\
120\end{array}$ & $\begin{array}{l}60 \\
80\end{array}$ & 80 \\
\hline & 3 & $\begin{array}{r}30 \\
170\end{array}$ & $\begin{array}{l}320 \\
110\end{array}$ & $\begin{array}{r}0 \\
100\end{array}$ & $\begin{array}{l}630 \\
160\end{array}$ & $\begin{array}{r}0 \\
90\end{array}$ & $\begin{array}{r}0 \\
100\end{array}$ & $\begin{array}{r}0 \\
140\end{array}$ & $\begin{array}{r}0 \\
60\end{array}$ & $\begin{array}{l}100 \\
630\end{array}$ & $\begin{array}{r}240 \\
\end{array}$ & $\begin{array}{l}420 \\
160\end{array}$ & $\begin{array}{l}250 \\
250\end{array}$ & 0 & 0 & $\begin{array}{l}550 \\
510\end{array}$ & $\begin{array}{l}180 \\
480\end{array}$ & $\begin{array}{r}0 \\
0\end{array}$ & $\begin{array}{l}0 \\
0\end{array}$ & $\begin{array}{l}0 \\
0\end{array}$ & 0 & $\begin{array}{r}80 \\
0\end{array}$ & 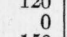 & $\begin{array}{r}80 \\
0\end{array}$ & $\begin{array}{r}90 \\
90\end{array}$ \\
\hline & 7 & $\begin{array}{l}260 \\
200\end{array}$ & $\begin{array}{l}100 \\
100\end{array}$ & $\begin{array}{l}100 \\
110\end{array}$ & 140 & 80 & $\begin{array}{l}100 \\
110\end{array}$ & $\begin{array}{l}140 \\
120\end{array}$ & $\begin{array}{r}60 \\
120\end{array}$ & $\begin{array}{r}630 \\
1,490\end{array}$ & $\begin{array}{l}1,550 \\
2,420\end{array}$ & $\begin{array}{l}160 \\
100\end{array}$ & $\begin{array}{l}11 \mathrm{C} \\
11 \mathrm{~s}\end{array}$ & $\begin{array}{r}70 \\
100\end{array}$ & 0 & $\begin{array}{l}210 \\
140\end{array}$ & $\begin{array}{l}190 \\
160\end{array}$ & $\begin{array}{l}130 \\
110\end{array}$ & $\begin{array}{l}80 \\
70\end{array}$ & $\begin{array}{l}100 \\
110\end{array}$ & $\begin{array}{r}90 \\
110\end{array}$ & $\begin{array}{l}170 \\
120\end{array}$ & $\begin{array}{l}150 \\
130\end{array}$ & $\begin{array}{l}10 \\
90\end{array}$ & $\begin{array}{r}40 \\
110\end{array}$ \\
\hline & & & 120 & 110 & 120 & 100 & & & & & & & & 110 & & & & & & & & & & & $12 J$ \\
\hline
\end{tabular}




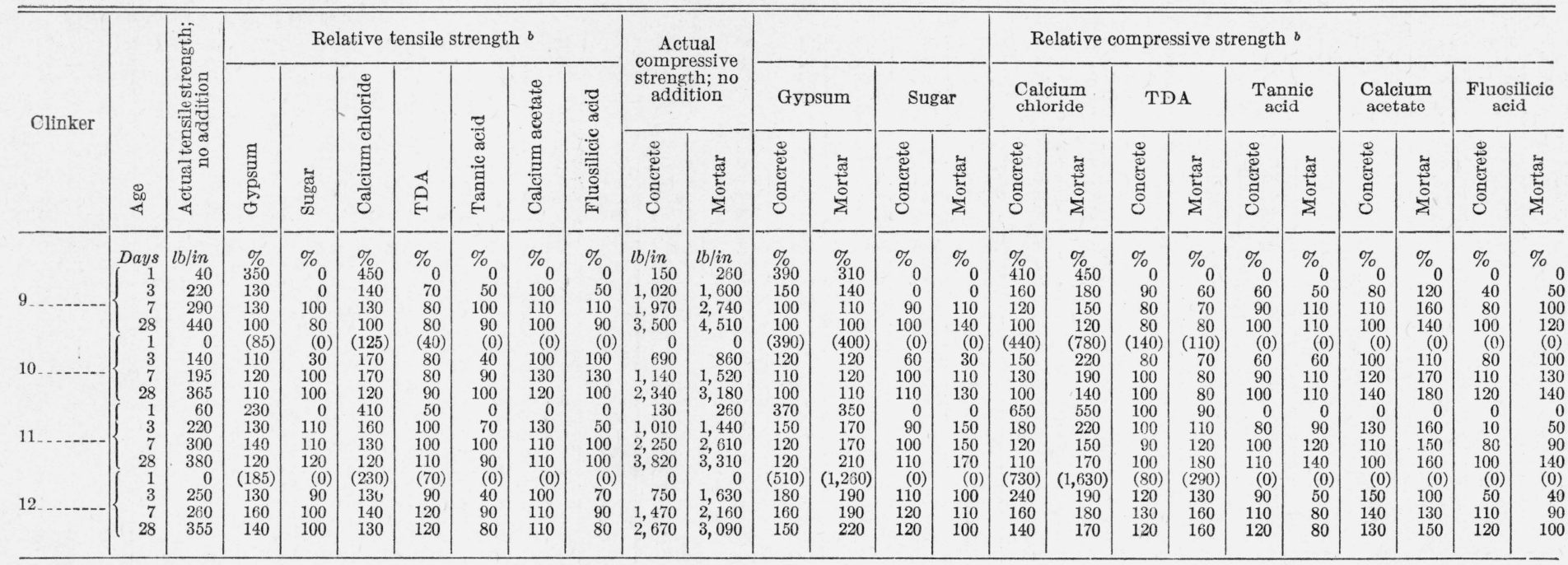

a At 7 minutes.

These strengths are expressed as percentages of the strengths of the similar specimens without addition.

- Figures in parentheses are the actual strengths in pounds per square inch. 
It is considered that variations of the strengths between 90 and 110 percent should be classified as not significant. A close examination of table 8 will show exceptions, but in general the effects of the added materials were as follows:

Gypsum and calcium chloride increased nearly all the strengths, both tensile and compressive, sometimes by several hundred percent at the early ages. The increases caused by calcium chloride were usually larger than those caused by gypsum.

Sugar reduced nearly all the 1-day strengths to zero. Clinker 2 was an exception. At 3 days, clinker 9 developed no strength, but only a few of the other clinkers showed a reduction and several showed an increase. At 7 and 28 days many of the strengths were increased. Notwithstanding the fact that sugar is generally considered harmful, it is apparent that in the amounts added in these tests, it did not reduce the strengths developed by the clinker pastes after the first few days.

TDA (together with the water in which it was dissolved, 0.23 percent by weight of the clinker) reduced to zero the 1-day strengths of two of the clinkers. A few of the strengths at 1 day were increased, but the majority were either unchanged or reduced by TDA. At 7 and 28 days the tendency of TDA was, with a few exceptions, to change the strengths by only small amounts.

Tannic acid reduced nearly all the 1-day strengths to zero. At 3 days many of the strengths were decreased and only a few were increased. At 7 and 28 days in the majority of cases, tannic acid had little effect on the strengths.

Calcium acetate reduced the 1-day strengths of a majority of the clinkers. In five cases the strengths were reduced to zero. However, in a few cases rather large increases in the 1-day strengths were caused by calcium acetate. At the later ages, calcium acetate increased the strengths of a majority of the clinker pastes.

Fluosilicic acid reduced nearly all the 1-day strengths to zero. Here again clinker 2 was an exception. At 3 days the majority of the strengths were reduced, but at 7 and 28 days the strengths were left unchanged or slightly increased by fluosilicic acid.

\section{SUGAR SOLUBILITY AND FLOC TESTS}

The results of the sugar-solubility test are reported in table 9 . Although the Merriman test was designed for use with cements, i.e., clinker plus gypsum, it may be of interest to consider the effects of the additions on the clinkers in terms of the ability of the material to pass the sugar-solubility test. The highest permissible "clear point". a cement may show and pass the test is $10 \mathrm{ml}$ of $0.5 \mathrm{~N} \mathrm{HCl}$. It will be seen that only three clinkers are below this limit. Gypsum lowered all the clear points sufficiently for three clinkers having high clear points to be included in the group below $10 \mathrm{ml}$ of $0.5 \mathrm{~N} \mathrm{HCl}$. Calcium chloride increased the clear points of many of the clinkers, whereas TDA affected them only slightly. Tannic acid decreased nearly all the clear points by rather large amounts in some cases, and brought two clinkers having high clear points into the group having clear points of less than $10 \mathrm{ml}$ of $0.5 \mathrm{~N} \mathrm{HCl}$. Triethanolamine increased most of the clear points but decreased a few, in one case sufficiently to include the clinker in the group passing the test for cement. Calcium acetate slightly increased the majority of 
the clear points. Fluosilicic acid lowered all the clear points, sufficiently for six clinkers with high clear points to include them in the group having clear points of less than $10 \mathrm{ml}$ of $0.5 \mathrm{~N} \mathrm{HCl}$. None of the materials caused the clear points of the three clinkers, No. 1, 5, and 9 , to increase sufficiently to exclude them from the group passing the sugar-solubility test for cement.

TABLE 9.-Results of Merriman sugar-solubility test on cement clinkers with and without added materials

\begin{tabular}{|c|c|c|c|c|c|c|c|c|c|}
\hline \multirow[b]{2}{*}{ Clinker } & \multirow[b]{2}{*}{ a Filtrate } & \multicolumn{8}{|c|}{ Volume of $0.5 \mathrm{~N}$ hydrochloric acid used in titration } \\
\hline & & $\begin{array}{l}\text { No ad- } \\
\text { dition }\end{array}$ & $\begin{array}{l}\text { Gyp- } \\
\text { sum }\end{array}$ & $\begin{array}{l}\text { Calci- } \\
\text { um } \\
\text { chlor- } \\
\text { ide }\end{array}$ & TDA & $\begin{array}{c}\text { Tannic } \\
\text { acid }\end{array}$ & $\begin{array}{l}\text { Trieth- } \\
\text { anol- } \\
\text { amine }\end{array}$ & $\begin{array}{c}\text { Calci- } \\
\text { um } \\
\text { acetate }\end{array}$ & $\begin{array}{l}\text { Fluosi- } \\
\text { licic } \\
\text { acid }\end{array}$ \\
\hline & & $m l$ & $m l$ & $m l$ & $m l$ & $m l$ & $m l$ & $m l$ & $m l$ \\
\hline 1. & $\left\{\begin{array}{l}\mathrm{Ep} \ldots \\
\mathrm{Cp}\end{array}\right.$ & 2.1 & 2. 0 & 1. 6 & 1.9 & 1.9 & 2.1 & 1.9 & 1.6 \\
\hline & 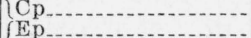 & 2.1 & 27.0 & 1.6 & 1.9 & 1.9 & 2.1 & 1.9 & 1.6 \\
\hline & $\left\{\begin{array}{l}\mathrm{Ep} \\
\mathrm{Cp} \mathrm{p}_{-.-.}\end{array}\right.$ & 40 & $\begin{array}{l}27 \\
32\end{array}$ & $\begin{array}{l}28 \\
37\end{array}$ & $\begin{array}{l}35 \\
46\end{array}$ & 44 & 37 & $\begin{array}{l}35 \\
44\end{array}$ & $\begin{array}{l}30 \\
39\end{array}$ \\
\hline 3. & Ep & 43 & 38 & 44 & $\begin{array}{l}40 \\
42\end{array}$ & $\begin{array}{l}58 \\
39\end{array}$ & $\begin{array}{l}40 \\
45\end{array}$ & 46 & $\begin{array}{c}39 \\
4.0\end{array}$ \\
\hline & Cp... & 61 & 50 & 63 & 60 & 55 & 63 & 63 & $\begin{array}{l}4.0 \\
4.0\end{array}$ \\
\hline 4 & $\left\{\begin{array}{l}\mathrm{Ep} \mathrm{p}_{-.-} \\
\mathrm{CP}\end{array}\right.$ & $\begin{array}{l}27 \\
37\end{array}$ & 3. 2 & 33 & 27 & 2.3 & 2.4 & 27 & 2.1 \\
\hline & 1. & $\begin{array}{c}37 \\
2.3\end{array}$ & 3. 2 & 46 & 38 & 2.3 & 2.4 & 38 & 2. 1 \\
\hline & $\left\{\begin{array}{l}\text { Ep }-- \\
\mathrm{Cp}-.\end{array}\right.$ & $\begin{array}{l}2.3 \\
2.3\end{array}$ & 2.4 & 2.3 & 2. 6 & 1.9 & 2.4 & 2.0 & 1.7 \\
\hline & SEp.-. & 25 & $\begin{array}{l}2.4 \\
7.7\end{array}$ & $\begin{array}{c}2.3 \\
29\end{array}$ & 25.6 & 13 & 22.4 & 26 & 1. 7 \\
\hline & $\mathrm{C}$. & 36 & 8.7 & 44 & 36 & $\begin{array}{l}13 \\
19\end{array}$ & $\begin{array}{l}22 \\
32\end{array}$ & $\begin{array}{l}25 \\
38\end{array}$ & $\begin{array}{l}2.7 \\
2.7\end{array}$ \\
\hline 7. & Ep & 41 & 34 & 43 & 42 & 43 & 42 & 43 & 31 \\
\hline & $\{\mathrm{Cp}$ & 63 & 49 & 66 & 65 & 67 & 66 & 66 & 55 \\
\hline 8 & $\left\{\begin{array}{l}\mathrm{Ep} \\
\mathrm{Cp}\end{array}\right.$ & $\begin{array}{l}22 \\
33\end{array}$ & 10. 1 & 29 & 26 & 6.8 & 24 & 29 & 2.3 \\
\hline & SEp... & $\begin{array}{l}33 \\
2.6\end{array}$ & $\begin{array}{r}12.4 \\
2.5\end{array}$ & $\stackrel{42}{2}, 7$ & 38 & 8. 2 & 36 & 43 & 2. 7 \\
\hline 9 & $\left\{\begin{array}{l}\mathrm{L}_{0} \mathrm{p}_{-. .} \\
\mathrm{Cp}\end{array}\right.$ & 2.6 & $\begin{array}{l}2.5 \\
2.5\end{array}$ & $\begin{array}{l}2.7 \\
2.7\end{array}$ & $\begin{array}{l}2.6 \\
2.6\end{array}$ & $\begin{array}{l}2.3 \\
2.3\end{array}$ & $\begin{array}{l}2.8 \\
2.8\end{array}$ & $\begin{array}{l}2.6 \\
2.6\end{array}$ & 1.7 \\
\hline & $\mathrm{Ep}$ & 19 & 7. 3 & 21 & 22.0 & $15^{\circ}$ & $22{ }^{\circ}$ & 24.0 & $\begin{array}{l}1.7 \\
5.5\end{array}$ \\
\hline & $\{\mathrm{Cp}$ & 25 & 11. 3 & 26 & 26 & 19 & 30 & 32 & $\begin{array}{l}0.5 \\
7.8\end{array}$ \\
\hline 11. & \& $\mathrm{Ep}_{-}$ & 32 & 7.5 & 38 & 33 & 24 & 30 & 34 & 1.8 \\
\hline & C & 39 & 8.4 & 57 & 39 & 38 & 46 & 51 & 1.8 \\
\hline 12 & $\left\{\begin{array}{l}\mathrm{Ep} \\
\mathrm{Cp}\end{array}\right.$ & $\begin{array}{l}49 \\
72\end{array}$ & $\begin{array}{l}45 \\
65\end{array}$ & $\begin{array}{l}52 \\
74\end{array}$ & $\begin{array}{l}49 \\
71\end{array}$ & $\begin{array}{l}47 \\
70\end{array}$ & $\begin{array}{l}48 \\
70\end{array}$ & $\begin{array}{l}49 \\
72\end{array}$ & $\begin{array}{l}30 \\
47\end{array}$ \\
\hline
\end{tabular}

a Ep, end point; Cp, clear point.

The weights of the ignited precipitates obtained in the floc tests are given in table 10 as percentages of the total weights of clinker taken. In a few determinations, part of the hardened clinker sloughed off during filtration and was included in the weight of the floc. This accounts for the high values obtained in a number of cases. In general, the added materials affected the results of the floc test only slightly.

TABLE 10.- Results of Paul floc test of cement clinkers with and without added materials

[Floc in percent by weight of clinker. All observed quantities of floc were "none" except for gypsum with clinkers $3,4,6$, and 12 , which were "small", and clinkers 7 and 11, which were "medium"]

\begin{tabular}{|c|c|c|c|c|c|c|c|c|c|}
\hline Clinker & $\begin{array}{l}\text { No ad- } \\
\text { dition }\end{array}$ & $\begin{array}{l}\text { Gyp- } \\
\text { sum }\end{array}$ & Sugar & $\begin{array}{l}\text { Calcium } \\
\text { chloride }\end{array}$ & TDA & $\begin{array}{c}\text { Tannic } \\
\text { acid }\end{array}$ & $\begin{array}{l}\text { Trieth- } \\
\text { anolan- } \\
\text { ine }\end{array}$ & $\begin{array}{c}\text { Cal- } \\
\text { cium } \\
\text { acetate }\end{array}$ & $\begin{array}{l}\text { Fluo- } \\
\text { silicic } \\
\text { acid }\end{array}$ \\
\hline 10 & $\begin{array}{r}\% \\
0.1 \\
.3 \\
.1 \\
.1 \\
.2 \\
.1 \\
.2 \\
.3 \\
.3 \\
.2 \\
.2 \\
.4\end{array}$ & $\begin{array}{r}\% \\
0.5 \\
.3 \\
.3 \\
.2 \\
.2 \\
.5 \\
2.4 \\
0.3 \\
.3 \\
.2 \\
1.3 \\
0.7\end{array}$ & $\begin{array}{r}\% \\
0.1 \\
.4 \\
.1 \\
.2 \\
.2 \\
.2 \\
\mathrm{a} 10.0 \\
0.3 \\
.3 \\
.2 \\
.3 \\
.4\end{array}$ & $\begin{array}{r}\% \\
0.2 \\
.7 \\
.2 \\
.3 \\
.2 \\
.2 \\
.5 \\
.3 \\
.3 \\
.2 \\
.3 \\
.4\end{array}$ & $\begin{array}{r}\% \\
0.2 \\
.4 \\
.3 \\
.2 \\
.2 \\
.2 \\
.7 \\
.3 \\
.3 \\
.2 \\
.3 \\
.3\end{array}$ & $\begin{array}{r}\% \\
0.8 \\
.2 \\
\text { a } 1.0 \\
0.3 \\
.2 \\
.3 \\
\text { a } 7.6 \\
0.3 \\
.3 \\
.2 \\
\text { a } 4.8 \\
\text { a } 4.7\end{array}$ & $\begin{array}{r}\% \\
0.3 \\
.6 \\
.3 \\
.2 \\
.2 \\
.3 \\
.9 \\
.3 \\
.3 \\
.2 \\
.3 \\
.3\end{array}$ & $\begin{array}{r}\% \\
0.3 \\
.4 \\
.3 \\
.2 \\
.1 \\
.2 \\
.2 \\
\mathrm{a} .1 \\
0.2 \\
.3 \\
.2 \\
.2 \\
.3\end{array}$ & $\begin{array}{r}\% \\
0.1 \\
.2 \\
.1 \\
.1 \\
.1 \\
.2 \\
\mathrm{a} 7.7 \\
0.3 \\
.2 \\
.2 \\
\mathrm{a} 3.0 \\
0.5\end{array}$ \\
\hline
\end{tabular}

a Particles of clinker included in weight of floc. 


\section{SUIMMARY}

The effects of added materials on 12 commercial portland cement clinkers were studied by comparing the results of tests of clinker samples containing the various additions with the results of identical tests of the clinkers alone. Determinations were made of (1) the temperature changes of the clinker pastes during one or more days after mixing, (2) the heats of hydration of the clinkers, (3) the tensile and compressive strengths of mortars and the compressive strengths of concretes, (4) the consistencies of concretes, (5) the sugar solubilities of the clinkers according to Merriman's method, and (6) the amounts of floc developed by the clinkers according to Paul's test. The materials added were gypsum, sugar (sucrose), calcium chloride, TDA, tannic acid, triethanolamine, calcium acetate, and fluosilicic acid.

It was found, in general, that while the added materials sometimes caused marked changes in the behavior of the clinker pastes during their early history, these changes were practically negligible at 28 days.

\section{REFERENCES}

[1] G. L. Kalousek, C. H. Jumper, and J. J. Tregoning, J. Research NBS 30, 215 (1943) RP 1530.

[2] T. Merriman, Rock Products 41, 87 (January 1938).

[3] I. Paul, Proc. 12th Annual Convention Assn. Highway Officials N. Atlantic States, p. 140 (1936).

[4] R. H. Bogue, Ind. Eng. Chem., Anal. Ed. 1, 192 (1929).

[5] L. A. Wagner, Proc. Am. Soc. Testing Materials 33, pt. 2, 553 (1933).

[6] Federal Specification SS-C-191b (April 29, 1941).

[7] P. H. Bates, Proc. Am. Concrete Inst. 25, 88 (1930).

[8] G. L. Kalousek, C. H. Jumper and J. J. Tregoning, Rock Products 44, 52 (April 1941).

[9] C. H. Jumper and G. L. Kalousek, Rock Products 45, 54 (April 1942).

[10] R. W. Carlson and L. R. Forbrich, Ind. Eng. Chem., Anal. Ed. 10, 382 (1938).

Washington, December 9, 1942. 